\title{
Tiempo e historia, presupuestos teológicos e intencionales de eternidad
}

A.-TIEMPo E HISTORIA.

¿Qué es el tiempo? Una pregunta que atormentó y sigue atormentando a las inteligencias humanas. Se ha pensado mucho, se ha escrito mucho y se ha discutido muchísimo; y la pregunta aún sigue en pie, sin una definición concreta y satisfactoria para todos. San Agustín también se la hizo; discurrió mucho sobre el tema, y terminó por decir con sinceridad: "Si nadie me lo pregunta, lo sé ; pero si quiero explicárselo al que me lo pregunta, no lo sé" ${ }^{1}$.

¿Existe el tiempo como un algo, como ser, o como cualidad del ser? Si fuera algo, ya sabríamos a qué atenernos. ¿Será más bien una cualidad del ser? San Agustín lo hace coincidir con una cierta distensión del áni$m o^{2}$, de la vida; y de la vida tomada no sólo en cada hombre, sino en el conjunto de la humanidad. Al igual que hizo Ortega; porque para Ortega y Gasset la radicalización del tiempo viene precedida por la radicalización de la vida. Sólo la vida explicaría el tiempo, o los seres vivos, mejor; pero los seres vivos en sucesión constante y en contingencia. Dios - no es contingente- no tiene tiempo ${ }^{3}$, y es vida. Dios es vida y fuente de la misma; el tiempo y la vida en El se unifican y estrechan de tal modo, que, originando el tiempo, en El no son causa de tiempo. Dios está por encima de toda sucesión, si es que el tiempo es sucesión. Dios es, simplemente: un presente eterno ${ }^{4}$. Tanto, que, para que pueda

1 Conf. XI, 14, 17, PL. 32, 816.

2 Conf. XI, 23, 30; 26, 33, PL. 32, 821 у 822.

3 De gen. contr. Manich. I, 2, 3, PL. 34, 174-175. En las Confesiones y en casi todas las obras contra los maniqueos habla de la eternidad de Dios, como no sujeto al tiempo y autor del mismo.

4 Conf. I, 6, 10; XI, 13, 16, PL. 32, 665; 815 . 
haber tiempo, tiene que haber un no-tiempo: una eternidad, el no-sucederse los momentos en la vida.

Esta distensio es una passio, que surge de una actio, de una puesta en acción presente, y que quedaría definida así: distensio = pasio-actio. Es un sufrir el presente, sentido en sí mismo. Por eso, para San Agustín, el tiempo es extensio, algo longitudinal, que, al intensificarse, se convierte cn sufrimiento -passio-, como una toma de consciencia de que algo le pasa en la intimidad, dentro del sí-mismo-ánimo. Esta distensio animi, es extiende, desde el presente-actio-passio, hacia el pasado y hacia el porvenir; y cuando se tiende en el pasado, hasta puede disiparse, relajarse, olvidándose. Por otra dimensión del ánimo existe en la intimidad humana, no longitudinal-horizontal, sino vertical, que, en lugar de apagarse por el estiramiento, se concentra o se contrae en altura: es la atentio, o intentio, la presencia de consciencia de cada instante, cuando la atentio es más intensa.

San Agustín es muy amigo de la concordia-interés de contrarios. Y al hablar del tiempo la tiene muy en cuenta. El hombre está colocado en un lugar medio - sintesis- entre el tiempo y la eternidad. El se siente pecador, como todo hombre; y por serlo, es terreno de graciaeternidad -amor infinito de una misericordia infinita- y estadio de pecado - temporalidad de la contingencia, historia de lo mudable-. El f.ecador siente necesidad de salvación -contingencia que reclama estabilidad de gracia - , y que es campo propicio para que el amor de Dios actúe en él para asumirlo-levantarlo. El hombre viene a ser el demiurgo platónico, la abundancia más pobre. Con esta carga en la consciencia de sí, trata de llenar el vacío de su vida con la aspiración a lo infinito y a lo eterno; radicando él en un mundo de cambios, suspira por la inmortalidad de lo perenne, y trata de situar el centro de su ser todo en las alturas de lo permanente-eterno.

Hay que buscar una solución a estos dos tirantes humanos - lo horizontal y lo vertical- y no la encontraremos más que en la muerte, cuando lo longitudinal se centrará plenamente en lo vertical. Cuando se acaba la vida en el mundo, ya no hay ni pasado, ni porvenir; todo será un estar en presencia, todo en todo a la vez. Y la tazón es la siguiente: el tiempo pasa, los instantes se van, precisamente porque, siendo ésa su condición de ser, nos indican con ella que una presencia stante nos aguarda. Sólo se comprende la esperanza-futuro con la llegada de do que esperamos - presencia del amar- se nos haga presente en el 
gozo. Experimentar la plenitud del presente es el gozo eterno. Ya la csperanza desaparece en la llegada, porque no se puede ya concebir la búsqueda en el seno de la plenitud, a no ser que la forma de un dichoso descubrimiento nos haga caer en la cuenta de lo que ya poseemos. Nunca nos es idado gozar en el tiempo, ya que eso mismo exigiría una pasada del tiempo. Porque amamos la presencia, por eso mismo el alma es lo que constantemente nos identifica en las fluencias del instante.

La espera y la esperanza definen, no dos momentos del tiempo, sino dos direcciones del espíritu. La espera, perteneciendo al orden del deseo -desiderium - es dirección al futuro, pero con una carga de materialidad-bien, felicidad, gusto y placer. La esperanza nos orienta y sumerge en lo infinito. Encerrando la esperanza un deseo-studium, votum, amor-, al estar orientada hacia bienes intemporales, es más certeza que deseo, porque, como certeza, en ella encontramos un no sé qué de posesión anticipada, y que no implica confusión alguna. "Esperar es aguardar io que no puede defraudarnos" - ha dicho J. Guitton-. La espera entraña la imperfección del paso de los momentos del tiempo, en los que nunca estamos seguros de alcanzar lo que esperamos. La esperanza debe su incertidumbre, principalmente, a la debilidad de la voluntad humana, porque si se está siempre en la firmeza del hacer noble, la esperanza se convierte ya en certeza, porque es visión clara del entendimiento y convicción profunda de la voluntad. La esperanza ya casi posee; la espera engendra inquietud con las horas lentas. La esperanza siempre está atravesada de la paciencia, que es sabiduría para la esperanza, porque el que es paciente siempre está también atravesado de esperanza. Esperanza y paciencia andan siempre juntas y a la par.

Sigamos con la distensio animi de San Agustín. Es muy importante para el Obispo de Hipona saber qué es el tiempo, y poder nosotros comprender también qué entiende y cómo estudia la historia. San Agustín hace mucho hincapié en el tiempo presente; tanto, que llega a decir que sólo existe el tiempo-presente, y casi ni el presente, porque nada más pensarlo, se nos $\mathrm{va}^{5}$. Hay un presente-presente, presente-pasado y presentejuturo $^{6}$. El pasado ya no nos pertenece, porque no existe. El futuro aún

5 Conf. XI, 11, 13; 15, 18-20, PL. 32, 804; 816-817.

6 Tempora sunt tria: praeteritum, praesens et futurum, sed fortasse proprie diceretur: tempora sunt tria, praesens de praeteritis, praesens de praesentibus, praesens de futuris. Sunt enim haec in anima tria quaedam et alibi ea non video, praesens de praeteritis memoria, praesens de praesentibus continuitus, praesens de futuris expectatio (Conf. XI, 20, 26, PL. 32, 819). 
no es. Luego, lo presente, la presencialidad es importante para explicar lo histórico y el hombre. Todo tiene un sentido; pero desde la radicalización del presente: el pasado fue presente; el futuro será presente y pasado. No son ni futuro ni pasado, si no se los relaciona con un presente; y el presente no se explica más que por sí mismo, no por el pasado ni por el futuro, por sí solo. No en vano es un remedo de do eterno. Eso es el presente: señalización de la eternidad, o desaparición del tiempo. Extraña cualidad la del presente, que en su misma actualización temporal tiene abierta la dirección a la cierta intencionalidad al Ser-Presente, a Dios-Eterno.

Luego, no se puede considerar, en sentido agustiniano, la historia, sino sólo la significación de presente y de acción. No es futurista San Agustín; le gusta la realidad tangible, como la verdad siempre presente. $\mathrm{Si}$ considera algunas veces a la historia como la magistra vitae, es sólo en función de un presente didáctico y dinámico, y no en sentido futurista como a primera vista aparecería. La historia como recuerdo no le interesa a San Agustín, ni a nosotros. El recuendo, como recuerdo, no es vida, no influye en la acción, ni en la salvación. Tampoco podemos ver matiz alguno preterista en la interpretación agustiniana de la historia. La historia es un poema humano ${ }^{7} ; y$, como poema, realización por la técnica de la antítesis ${ }^{8}$, en la que los contrastes realzan las creaciones humanas ${ }^{9}$. La presencia le llena por completo, porque es el reino de la verdad, que es lo que es ${ }^{10}$.

El hombre también es un presente; y si lo es, ¿son las cosas las que se le van cargando, o es él el que se extiende sobre las cosas? En los dos casos es el hombre presencialidad y presencialidad no-pasiva, sino actuante, que se va haciendo en el presente, en cada instante. Sólo así es el hombre creador de la historia, e historia misma. Si el hombre es acción y vida, éstas sólo significan en el presente; el hombre lo mismo, cuya es la vida y la acción. Es que vida y acción sólo pueden ser presente; y las vidas que fueron y las acciones que se realizaron, sólo toman significación en relación al presente, porque fueron presentes, porque fueron

7 De ver. Relig. 22, 43, PL. 34, 140.

8 De civit. Dei XI, 18, PL. 41, 367-368.

9 Así va transcurriendo la hermosura de las edades, cuyas partículas son aptas para cada una a su tiempo, como un gran cántico de un inefable artista para que los que adoren dignamente a Dios pasen a la contemplación eterna de la hermosura mientras dura el tiempo de la fe (Epist. 138, I, 5, PL. 33, 527; Ibid. 166, 5, 13, PL. 33, 726).

10 Solil. II, 4, 5, PL. 32, 887-888. 
y se realizaron en el presente suyo, y por eso pueden ser presente-memoria, recuerdo. Porque el presente, en su sentido esencial radical, se plantifica, como saliéndose del tiempo discurrente; por eso mismo, es reducible a la acción. Si el hombre es un hacerse, es porque se actualiza y se constituye en sí mismo en su presente dado y tomado. El presente no es el tiempo-ahora, ni la duración-instante, es una imposición del sí en el si-mismo, del hombre en el ahora. Si existe algo, es porque algo nos es presente. El sernos-presente para nosotros, eso es el tiempo. El ser yo en las cosas, y el ser las cosas en mí, eso es mi tiempo: yo soy presencia, y ellas me son presencia. Así, todo mi pasado y todo mi futuro, en mí, sólo tiene valor, porque el pasado me fue presente y el futuro me lo será. Luego la historia humana también es un presente, y presente irrepetible.

Los hechos, en indiependencia, no tienen historia; son opacidad, no dicen nada; hay que estudiarlos, no en el pasado, sino en un presente, en el suyo y en el mío. Así lograremos el significado de posición humana y de libertad humana al realizarse y al comprenderlos.

Si los miramos como puro pasado, ya no son. Sólo cobran razón de verdad en presente. Siendo el hombre actualización de sí, en virtud de su persona y de su razón libre, es por lo que el hombre, a lo largo de su vida-existencia, es siempre el mismo: se está siempre presente a sí mismo, siempre, poseyéndose como la misma idéntica persona.

Sólo el presente nos explica la razón y hasta el ser del hombre, que necesita estar en acción constante $-y$ lo está siempne-, para mantenerse en sistencia. El estar-en-acción, que es el presente, se orienta y desarrolla en el hacerse del hombre, incluso intelectualmente. Y si el hombre se hace en el presente, es porque siempre actúa en el presente, y porque se define en su presente, que es el hacerse o constituirse el hombre. Luego, por ser el hombre un hacerse y porque se hace en su presente, el presente define al hombre como un ser que se hace lo que es.

Este hacerse del hombre no se conforma en el presente al estilo griego, eleático, que es implantación de lo humano en un estancamiento jnoperante, o meramente contemplativo, como expresión de normas dadas, sino que nuestro presente es constitución y actualización de acción interna y externa. La autocreación del hombre, por ejemplo, en sentido helénico, no significa una propulsión a la acción, sino a una contemplación, que es estatismo, en parada, no es el operar activo y decurrente o recurrente de nuestra concepción humana del hombre, concepción también agustiniana. Sólo con esta acción de esfuerzo en cada presente el 
hombre separa su ser del ser indeterminado de las cosas. Este hacerse entraña en el hombre, además del presente, una intencionalidad de trascendencia hacia algo superior a él. Si no fuera el hombre en el presente, todo él quedaría inmerso en el mundo de la inmanencia, como lo otro que no es él. Esta intencionalidad la posee gracias a que su presente lo coloca en libertad, como posibilidad de acción, de esta o de otra manera. Porque el hombre es un hacerse, no es aun un hecho, sino un factible; de ahí su posibilidad, que le regala la libertad de su persona racional, o su racionalidad, que es siempre un presente-tiempo humano.

Se ha venido definiendo al tiempo como una duración, o una sucesión de instantes. Para nosotros lo importante en el tiempo no es la duración ni la sucesión, sino el instante, lo que instat -lo que está, lo que se pone o se halla delante, en o sobre-, eso que dura y que no es la duración: eso es el tiempo. Ahora bien, ¿qué cosa, o quién está en, se pone, o se halla en o sobre? ¿El tiempo, el instante, el presente? No; de ninguna manera. Soy yo, somos nosotros los que nos ponemos, o nos hallamos, o nos estamos en; o sobre, o delante. Nadie más, ni ninguna otra cosa. Las cosas no se ponen, las colocamos o las encontramos nosotros. Lo que queda entre el pasado y el futuro será el presente; y yo hago mi presente, porque me inserto en él. Si esto es así, nos quedamos con el tiempo puro, como con una reducción fenomenológica, que se nos da en la intimidad de nuestra conciencia. El tiempo es abstracción nuestra. Pero, no; no creamos nosotros el tiempo; el tiempo se nos da, se nos impone, o nos lo encontramos. Luego, es algo. ¿Qué es? Eso: tiempo presente y nada más. El tiempo no es división de instantes que pasan; es eso que siempre está en nosotros, que nosotros asumimos en la intimidad. Luego, para mí ya no es abstracción, ni algo en puridad: es algo real, porque yo sólo tomo o pienso realidades, aunque sean de tipo ideal. Además, todo lo que existe es real; y el tiempo existe; nada más cierto.

El pasado y el futuro no se comprenderían sin una relación de presente. El pasado es real, porque se hizo presente alguna vez; y, desconectado del presente, sería pura ilusión; no abstracción, sino ilusión. Es pasado, no porque haya dejado de existir en el presente, sino porque desde mi presente lo miro ya como pasado; y que puede influir en mí sólo con relación de presente, no como pasado u ocurrido. Si es algo real, es porque es actual, y lo actual sólo opera en el presente. Así, el pasado, actualizado en un presente, sólo puede ser hecho histórico, porque una relación lo une con el presente. 
El futuro, si es que se puede conocer - predecir sería lo propio-, lo conocemos desde el presente. El futuro es radicalmente esperanza. La esperanza está en nosotros que esperamos, y que en nosotros se nos da como una cuasi-realidad. Al tender hacia algo, que no está a nuestro alcance, nos lanzamos, y en nuestro lanzamiento realizamos la esperanza, porque es creencia de realidades posibles. Lo mismo que para el pasado -que es lanzamiento hacia atrás por el recuerdo-memoria de quien es presente-, con el futuro sucede algo parecido: sólo quien esté presente puede lanzarse hacia adelante, desde el presente, hacia el porvenir, y afianzarse en la esperanza, creyendo que va a conseguir una realidad. Esperanza y creencia son postulados de futuro. De tal forma, que para conocer cómo será alguien en su futuro, tenemos que conocer cómo es su presente, y narrar lo que ha sido en el pasado. Lo mismo para averiguar un suceso en el porvenir; tenemos que entender el presente y comprender el pasado. Así, la historia, para que sea completa, no sólo explica acontecimientos del pasado, no sólo mira al pretérito, sino que también explica el presente y tiene una trazón para el futuro.

El tiempo es irreversible, mirando al pasado en contra del retorno eterno de los griegos, o del corso e ricorse de Vico. El tiempo es irreversible; y no sólo el tiempo, sino también el hombre es irrepetible, port que ya no es capaz de volver sobre sus pasos para desandar el camino. Siendo un incesante constituirse, su destino es estar en ruta por la puerta de la esperanza, andar siempre, y hacia adelante, y nunca hacia el pasado. Una experiencia o vivencia humana nunca puede ya repetirse: siempre hay algo que la diferencia y la distancia de otra pasada, aparentemente la misma. Es la situación, o la circunstancia lo que hace siempre distinción. Esto es indudable. El tiempo no se repite, porque el hombre nunca puede darse la vuelta y debe caminar arrastrando consigo al tiempo.

Busquemos una razón a todo esto. Si el hombre es un presente constante, instante, y si este su presente define su ser en el hacerse, el pasado ya no puede definirlo, porque ya no está en su dominio. El hacerse del hombre -el presente- es lo que le hace no ser pasado. Luego, su ser de ahora y su ser del pasado, si son continuos, tienen la diferencia en la situación, o en la circunstancia. Luego su ser de ahora es no ser un ser-pasado. Es su posibilidad la que le impide el ser pasado; o mejor, es su libertad la que siempre le empuja hacia adelante, y la que le prohibe volver la espalda. No volver la espalda es lo mismo que permanecer en 
identidad constitutiva; y ésta es sólo propia de quienes son dueños de sí mismos: una piedra será siempre la misma e idéntica en su estar-ahí, porque no tiene un hacerse; lo único que le puede suceder es que se le aumente de tamaño, o que se le cambie de situación-lugar — no en el espacio-tiempo-, y quedará aún idéntica a sí. No podemos decir lo mismo del hombre. Porque si es idéntico a sí mismo, lo es gracias a su personalidad, no al pasado. Además lo que redlama la persona es siempre un presente - su presente-, como fondo de posibilidades. La consistencia del hombre es el ser, no el estar, que le es común con las cosas. Y el ser siempre empuja; no así el estar, que es, por definición, quietismo. Luego el pasado del hombre, pasado que existe, es pasado e influye en él, porque es un presente en la intimidad racional del ser racional. Así se explica también, no sólo su trascendencia, sino hasta el ansia de inmortalidad y sistencia en espiritualidad, que el espíritu reclama esencialmente la presencia como tiempo presente.

El tiempo le adviene al hombre como si él lo engendrara; y, por eso, el tiempo es suyo; y con el tiempo comienza su historia, y la coloca dentro de la historia de la humanidad. Una vez que el hombre arranca para el mundo con el tiempo-inicio, se coloca en la permanencia del tiempo-existencia: nace y ya no desaparece, porque siendo inmortal, su alma reclama para el tiempo-existencia también al cuerpo, para volver a formar unión existencial. Al tiempo-vida es al que tratamos de dominar, porque en él nos hacemos, hasta llegar al aevum, tiempo-existencia. Si en este tiempo-vida es donde se nos manifiestan los valores vitales, mundanos, y todos los valores del ser y de la verdad-bondad, y se nos manifiestan como históricos, es decir, como algo que tenemos que escoger para llegar a la perfección de la persona, y que permanecen como históricos -de paso para nosotros - en relación a nuestra vida telúrica, siendo en sí ellos puramente universales, lógico es concluir que a nosotros nos interesa saber nuestra relación con y con todos para no errar en el camino, y llegar lo más perfectos al tiempo-existencia.

El tiempo hace irreversible la historia como suceso: lo que ha sido, fue, nada más; y no puede volver a ser. Pero, presente en la memoria, continúa en el presente, en esa presencia racional nuestra, y como reposición voluntaria por el recuerdo, y no como un comienzo a ser nuevamente. El tiempo, al tener una realidad, es también unidad, unidad de presente, que hace avanzar al porvenir, actualizándolo, para hacerlo también ser-memoria. $\mathrm{Y}$, ya como memoria, se queda en la existencia y para 
la existencia; y así forma la historia. De esta manera la duración-yo -yo que soy duración - mide el movimiento, el pasar de la perfección y perfección y perfeccionamiento de los seres. La voluntad-ánimo poda, desecha o concentra el pasar de las horas en una presencia íntima de memoria, en la que se queda el tiempo como presencia de algo que fue presente y que es recuerdo de presente. Pero la duración no es ese constante suceder-pasar en la unidad del ánimo-yo ${ }^{11}$, sino el estar yo, mi yo, en la duración; no es cadena en la que cada eslabón es un acto, ni sucedense de actos, sino el permanecer con' esa experiencia de tales actos. Es el plantificarse de la voluntad en el acto mismo, como cuando uno "posa" para el fotógrafo, y se queda la imagen en la placa impresionada; y se recordará siempre aquella experiencia y aquella presencia.

También es cierto que el hombre camina sobre su pasado; de ahí su contingencia. Porque un presente es dirección siempre a un pasado en el tiempo-vida. $Y$ porque el hombre marcha sobre su pasado, no hay discontinuidad en su consistencia, y ni aún en su existencia. Pero, por lo demás, el pasado, aunque pisado por el hombre, se actualiza en el presente; tanto, que el pasado es el eje-arranque de mi vida en el presente: el pasado aún carga sobre mí, y me hace ser lo que soy, porque influye en mí -presente existenciall-. Es por esto por lo que el hombre es un ser con historia, histórico. El presente mío concluye y cienra mi pasado, lanzándome dentro del tiempo histórico. No porque yo cargue con mi pasado, éste tiene influencia definitiva para destruir mi libertad; todo lo contrario, porque yo soy presente y estoy en presente es por lo que pueda hacer que el pasado, si puede influir en mí, no ejerza influjo alguno: soy libre, y mi libertad me libera de la tarea del pasado, lanzándome a la esperanza del futuro.

Es verdad que el hombre se sitúa en el presente, que es conciencia. Pero su libertad-posibilidad lo lanza a realizaciones constitutivas de perfección en su ser. Pero, ¿a qué posibilidades? Dos caminos se le abren; por eso, la trascendencia se le presenta casi siempre en confuso. Cualquier relación entre el presente y un consiguiente, por ser producto de deducción, ésta la puede fallar al hombre, como la falla muchas veces la lógica, que puede ser ajena a la realidad. Nada se puede ver con claridad; y todo es igualmente expectable. Aún en este aparente discontinuismo histórico el hombre se puede realizar, porque siendo consciencia,

11 Conf. XI, 27, 36, PL. 32, 823-824, 
es también creencia, y la creencia se proyecta siempre al futuro con función de presente; de aquí la continuidad del ser humano y la continuidad de su hacer histórico; porque el futuro lo es sólo por el presente. Es fundamental esto en San Agustín: hay presente de las cosas pasadas -recuerdo-, presente de las cosas presentes $\rightarrow$ visión-, y presente de las cosas futuras - expectación ${ }^{12}$.

El hombre, por necesidad, tiene que constituirse, hacer su vida. La vida es un acontecer de y en el presente; y antes de hacer el hombre su vida, cada cual tiene que tomar asiento y reflexionar sobre sí y sobre lo otro, y decidir luego por cuenta propia su particular e ineludible destino. Ahora bien, la decisión se toma siempre en el presente, pero con perspectiva hacia el futuro; de tal modo, que todo es consecuencia real y lógica de un presente decidido. Y uno se decide siempre por la confianza y por la creencia: confianza en sí y creencia en lo demás. Creemos y confiamos en nosotros, y en lo otro. Greemos en realidades y confiamos en las mismas realidades. La creencia-confianza es objeto de actuar, y la decisión el sujeto: nosotros que decidimos seguir el camino de las creen(ias. Nosotros nos plantamos en la acción, porque decidimos seguir una creencia en que confiamos; así, nos lanzamos al futuro-presente. Así, nunca somos do que anteriormente fuimos. Esta es la historia.

El tiempo fue creado en simultáneo con el universo; y ese es su principio, no su origen, como si fuera un mundo temporal. Porque "lo que se hace en el tiempo, se hace después de algún tiempo y antes que alguno, después del pasado y antes del porvenir. Pero no podía ser pasado ninguno, porque no existía criatura al guna, cuyos mutables movimientos lo hicieran. El mundo fue hecho con el tiempo si en su creación fue hecho el movimiento mutable. Esto parece indicar también el orden de los seis o siete primeros días" ${ }^{13}$. Los profanos se equivocan en su teoría del tiempo repetitivo, una forma de eternidad del tiempo; se engañan por la "locura de la impiedad", porque atribuyen al mundo lo que sólo a Dios le conviene.

El tiempo abre el campo a la fe y a la esperanza, porque siendo el tiempo finito, un cúmulo de posibilididades se abre para la humanidad en la confianza de una promesa y una realidad de salvación por parte de Dios, cosa que no se puede afirmar ni oreer con el eterno retorno de los

12 Conf. XI, 20, 26, PL. 32, 849.

13 De civit. Dei XI, 6, PL. 41, 321-322, 
griegos, que, por lo mismo, no deja cabida a la esperanza, ni siquiera para una perspectiva ligera de salvación. El griego paraliza la esperanza, anula la fe, y destruye el amor ${ }^{14}$.

La historia, si es verdadera, narra la verdad de los sucesos. La verdad, como los hechos, puede tomarse en relación al tiempo. Puede situarse en presente, en pasado y en futuro. No tratamos aquí de la verdad ontológica, axiológica o epistemológica, que ésta, como verdad, es, simplemente, y permanece la misma sin atender a tiempo ni espacio: es lo que es ${ }^{15}$, siempre y sin cambios de tiempo ni de espacio. Tan cierto es esto, que los hechos no configuran la verdad, sino que es la verdad quien da valor a los hechos. Y así, la verdad es un a priori absoluto, que no depende de nada ni de nadie; es eso: absoluta, que se identifica con la otra Verdad, que es Dios. Los hechos y el tiempo no se miden en, con y por la verdad, que les precede y acompaña; es la verdad la que establece la escala de valores y a la que todo se ha de conformar: seres, espacio y tiempo. La verdad es anterior a todo lo existente; más aún: todo lo que existe es, porque dentro de sí lleva la vendad. Si el tiempo es, existe porque es verdad. La verdad no depende de los hechos, como pretenden los filósofos pragmático-materialistas, sino al revés: los hechos de la verdad.

La verdad siempre es perspectiva, lejanía u horizonte; nunca es un encierro o un estancamiento. La verdad avalla los hechos y afirma el presente, reduciéndolo todo a categoría de presencia. Es lógico afirmar esto, porque, siendo la verdad independiente de modo absoluto del tiempo, está fuera de él; pero a la vez envuelve ella al tiempo, haciéndolo presencia constante. Del lado de la verdad no hav más que presente. De nuestro lado - contingencia total - hay, además, pasado y futuro. La vendad es siempre presencia. Y si nosotros nos colocamos en lejanía de la verdad, es que la verdad no necesita de nosotros, y es que nosotros nos alejamos de ella por un escape culpable, y abrazamos el error.

La verdad, en el sentido agustiniano, anida en el ser, comensurándolo ${ }^{16}$; es el ser de las $\operatorname{cosas}{ }^{17}$ reales o ideales; no en el sentido de que los seres la circunden, sino en el de que la verdad es la razón de las esencias y consistencias: la verdad todo lo invade, y no como desea Male-

\footnotetext{
Ibid. XII, 13, 1 y 2, PL. 41, 360-362.

Solil. II, 4, 5, PL. 32, 887-888.

De ver. Relig. 36. 66, PL. 34, 151-152.

De Trinit. VIII, 1, 2, PL. 42, 947-948.
} 
branche, sino porque la verdad del ser es su misma realidad madura. Por esto, la verdad es acrónica, porque no tiene que ver nada con el sersiendo, porque ser y vendad son conceptos heterogéneos, o como diría Ortega y Gasset: "las verdades no se bañan en la ribera del tiempo". El ser sí, es temporal, porque él es contingencia. Pero también es cierto que la verdad se clarea en el ser, y que el ser manifiesta siempre la verdad; por eso, se puede hablar de una verdad de presente, de una verdad de pasado y de una vendad de futuro. No en el sentido de que la verdad sea distinta para cada flase del tiempo, sino en el de que cada ser, en su tiempo, manifiesta la verdad a su modo contingente, permaneciendo siempre idéntica la verdad en cada etapa de la historia. En el modo de su manifestación aparece como condicionada por la circunstancia, sin que ésta la absorba y conforme. Cada época contempla su parte de verdad, desde su perspectiva humana, desde su presente; porque la verdad y el presente son, y son sin reparación. La Verdad absoluta -Diosestá sobre el tiempo y es independiente del mismo. Pero la verdad participada, esa verdad de las cosas que ve y aprecia el hombre, sólo se da en el presente humano; y si se da relaciona a un pretérito o a un porvenir, sólo como presente es asumida por la inteligencia del hombre; porque la inteligencia humana es presente y sólo capta la verdad desde su presente-instante. De ahí que la verdad sólo la situemos en el presente, no desde el lado objetivo de la vendad misma, sino desde la circunstanciapresente-situación humana.

El tiempo en San Agustín no se toma en función del mismo, sino en función de las criaturas, desde los seres creados. Es tiempo psicológico. El tiempo viene a ser un modo de existencia, o muchos modos distuntos en que las criaturas se mueven. No es algo aparte de las cosas: serán las cosas las que, al moverse, engendran el tiempo y viven el tiempo y en el tiempo, no como algo real, sino algo subjetivo. Más aún: el tiempo sería para San Agustín imitación de la eternidad, como los seres lo son de Dios ${ }^{18}$; pero no en el sentido eleático del retorno eterno. El

18 Summus enim est, et non mutaris, neque peragitur in te hodiernus dies, ct tamen in te peragitur, quia in te sunt et ista omnia: non enim. haberent vias transeundi, nisi contineris ea. Et quoniam "anni tui non deficiant" (Ps. 101, 28), anni tui hodiernus dies. Et quam multi dies nostri et patrum nostrorum per hodiernum tuum transierunt et ex illo acceperunt modos et utcumque exstiterunt, et transibunt adhuc alii et accinient utcumque exsisterent (Conf. I, 6, 10, PL. 32, 665). Et vidi quia non solum locis sua quaeque suis conveniunt, sed etiam temporibus, et quia tu, qui solus aeternus es, non post innumerabilia spatia temporum. coepisti operari, quia omnia spatia temporum, et qui praeterierunt et quae praete- 
tiempo agustiniano es algo real, que tiene su comienzo en el andar de los seres, a quienes se les ha marcado un destino o una meta. Los seres, colocados en el tiempo, y el tiempo, envolviéndolos, realizan todos el ordo-temporis, quien, por ser real, realiza un proyecto eterno. Todos ellos cumplen con una imitación de eternidad en el tiempo, sí ; pero dentro de la eternidad que los envuelve. El tiempo tuvo su comienzo, y a la eternidad se dirige en su constante despliegue o desarrollo. El tiempo - si se nos permite la expresión - vendría a ser un punto de eternidad.

El tiempo se inicia en la creación ${ }^{19}$. Es engendrado por algo creado, supuesta ya la creación de todo. El moverse angélico engendra ya un tiempo especial, el angélico, por el que el presente pasa y se hace pretérito; y el futuro, presente y pasado; pero el pasado no se convierte en simple pasado, a lo humano, porque el pasado no deja de existir como si ya no fuese, ni el futuro se llega como si aún no hubiera existido. De aquí la originalidad del tiempo angélico. No es presencia, como en lo humano, conseguida como un despliegue del alma por sus facultades -memoria para el pasado, visión en el presente y esperanza-creencia para el futuro-, sino presencia ontológica, en cuya inmovilidad el ser se integra y no se derrama. Es un tiempo ahistórico, sin etapas de sucesión, pero sin llegar a identificarse en nada con la presencia absoluta e inmóvil de la eternidad. El tiempo angélico no es el nuestro, que es contingencia y transitoriedad ${ }^{20}$.

ribunt, nec abirent nec venirent nisi te operante et manente (Conf. VII, 15, 21. PL. 32, 744). Vicisitudo enim temporum sibi succedentium dum luna minuitur et rursus impletur, dum sol omnino anno locum suum repetit, dum ver, vel aestas, vel autumnus, vel hiems sic transit ut redeat, aeternitatis auaedam imitatio est (Enn. in ps. 9, 7, PL. 36, 120). (De gen. ad litt. imper. lib. XIII, PL. 34, 236-237; Enn. in ps. 147, 5, PL. 37, 1918).

19 ...et quoniam etiam tempus ipsum creatura est, incipit esse ut aliquid priusquam angelos factum accipiamus (De gen. ad litt. imper. lib. III, 7, PL. 34, 222). Cum igitur Deus, in cuius aeternitate nulla est omnino mutatio creator sit. temporum et ordinator... (De civit. Dei XI, 6, PL. 41, 321). (Cfr. Conf. XII, 15, PL. 32, 832).

20 Ideoque spiritus, doctor famuli tui, cum te commemorat fecisse in principium caelum et terra, tacet de temporibus, silet de diebus. Nimirum enim caelum caeli, ouod in principio fecisti, creatura est aliqua intellectualis, quam. nequaauam tibi, Trinitate, coaeterna, particeps tamen aeternitatis tua.e. valde mutabilem suam prae dulcedine felicisimae contemnlationis tuae cohibet et sine ullo lansu, ex quo facta est, inhaerendo tibi excedit omnem volubilem vicissitudinem temporum. Ista vero informitas, "terra invisibilis et incomposita", nec ipsa in diebus numerata est. Ubi enim nulla species, nullus ordo, nec venit 'auicquam nec praeterit. et ubi hoc non fit, non sunt utique dies nec virissitudo spatiorum temporalium (Conf. XII. 9, 9, PL. 32, 829). Item dixisti mihi voce forti in aurem interiorem, quod nec illa creatura tibi coaeterna est, cuius voluptas tu solus es teque perseverantissima castitate hauriens, mutabilitatem suam. 
Un modo parecido de tiempo correspondería al hombre en su estado primero de antes de pecar, porque, testificando y comprobando en sí la inconmutabillidad de la verdad, vivía de la contemplación de la misma; y en esta su contemplación todo el ser suyo humano se le integraría totalmente, y hasta la existencia de los demás se le daría en esa contemplación de integración suya con la Verdad inmutable. Una intensa unidad interna le impedía el despliegue al exterior, y le recordaba incesantemente su intimidad con el Creador. Por eso, afirma San Agrustín que no envejecerían nuestros primeros padres ni sus descendientes, porque el tiempo no marcaba en ellos huella destructora, permaneciendo todos en la estabillidad de la edad ${ }^{21}$. Con la caída de los ángeles y de los hombres se abrió el abismo a toda oriatura racional ${ }^{22}$; y con el pecado perdieron su original estabilidad, cambiando el tiempo de ritmo y sentido ${ }^{23}$.

San Agustín atribuye al pecado original, no sólo la mortalidad, sino también la temporalidad del ritmo y de la dirección. El pecado todo lo temporalizó, y sacó del centro de presión y de altura; y la stabilitas aetatis, en que el hombre fue creado, se la sustituyó por la mutabilitas aetatum, que le precipita en carrera veloz hacia la muerte. La mutabilitas aetatum es sucesión de etapas para el cómputo del tiempo, que se hizo caduco, y al hombre do hundió más en sí mismo al perder la original estabilidad, cuando perdió la juventud de la gracia, en que estaba inmerso ${ }^{24}$. Nuestro tiempo, pues, es proceso de desgaste y desgarramiento; la inquietud y el ansia definen nuestras situaciones humanas en el correr de los años. Con esto el pecado adquiere importancia para la interpretación de la historia en San Agustín; pues, por el pecado quedó el hombre a merced de sí mismo y a merced de las escasas fuerzas egoístas y

nusquam et nunquam exserit et te sibi semper praesente, ad quem tot affectu se tenet, non habens futurum quod exspectet, nec in praeteritum traiciens quod meminerit, nulla vice variatur nec in tempora ulla distenditur (Conf. XII, 11, 12, PL. 32, 830).

21 Quae licet senio non veterascerent, ut necesitate perducerentur ad mortem (qui status eius de ligno vitae, quod in medio paradiso cum arbore vetita simul erat, mirabile Dei gratia praestabatur)...; de ligno autem vitae propterea gustabatur, ne mors eius undecumque sobreperet, vel senectute confecta decursis temporum spatiis interirent: tanqam caetera essent alimento, illud sacramento; ut sic fuisse accipiatur lignum vitae in paradiso corporali, sicut in spirituali, hoc est intelligibile paradiso, Sapientia Dei, de qua scriptum est, Lignum vitae est amplectentibus eam (De civit. Dei XIII, 20, PL. 41, 394).

22 Conf. XIII, 8, 9, PL. 32, 848.

23 Remitimos al lector al interesante trabajo del P. R. FLórez, O. S. A.: "Temporalidad y tiempo en la Ciudad de Dios": La Ciudad de Dios 167 (1954) 169-185.

24 Non stat aetas nostra: ubique fatigatio est, ubique lassitudo, ubique corruptio (Enn. in ps, 62, 6, PL. 36, 752). 
depresivas suyas, en que se desenvuelve en el mundo por la deserción culpable.

A partir de este hecho histórico y humano nace un nuevo acontecer, una nueva onda de ritmo distinto, señalando profundamente la contingencia de la criatura: nace un tiempo herido y un tiempo que muerde, marcando más fuertemente las disonancias interiores, que se adentran en lo íntimo humano: tiempo de pecado y tiempo de muerte. La temporalidad del tiempo empecatado sumergirá al hombre y al mundo en un sucederse las etapas, en las que nace la historia, y que lleva también, como el tiempo, la marca de la mordedura de todo lo contingente. Con el pecado se sucede una serie inconmensurable de problemas en el mundo de lo creado, que Agustín interpreta al hablar de la creación, caída de los ángeles, en donde tienen origen las dos ciudades en el ritmo de dos amores distintos. También trata la creación del hombre y su pecado; y al pecado lo toma como una "razón increíble de esa sinrazón histórica que significa el pecado original" ${ }^{25}$, y a la libertad, como nota temporal humana ${ }^{26}$ y causante del pecado y de su consecuencia, la muerte. Si Adán no hubiera roto la melodía inicial del tiempo con su pecado, todo hombre habría alcanzado la inmortalidad de la criatura racional. Pero, pecó; y todo él se precipitó en la sentencia de un castigo de muente y en la pena de una contingencia enormemente sentida en el arrastre de lo humano. Ahí comenzó nuestro tiempo "inciento e inmaduro", y con el tiempo la historia. El tiempo-historia, en San Agustín, comienza por una autosuficiencia del espíritu, por el afán de autodominio, o por el afán de posesión exclusiva de sí mismo: quiso hacerse el hombre como Dios, y, en lugar de conseguirlo, se hizo como bestia. Y con la pérdida del autocontrol cayó en la profundidad de las cosas, de lo otro, que lo saca de sí, y lo envuelve en el torbellino del tiempo y de la autodisolución ${ }^{27}$.

25 P. R. FlóREZ, o. c. 179.

26 De civit. Dei, todo el libro XII, PL. 41, 347-376.

27 Quando ergo peccavit Adam non obediens Deo, tunc eius corpus, quamvis animale et mortale, gratiam perdidit, qua eius anima omni ex parte obediebat; tunc ille exstitit bestialis motus pudendus hominibus, quem in sua erubuit nuditate. Tunc etiam morbo quodam ex repentina est pestifera corruptione concepto factum est in illis, ut illa in qua creati sunt stabilitate aetatis amissa, per mutabilitas aetatum irent in mortem. Quamvis ergo annos multos postea vixerint, illo tamen die mori coeperunt, quo mortis legem, qua in senium veterascerent acceperunt. Non enim stat vel temporis puncto, sed sine intermissione labitur, quidquid continua mutatione sensim ourrit in finem, non perficientem, sed consumentem. Sic itaque impletum est quod dixerat Deus: Qua die ederitis, morte moriemini (De pecc. mert. et remiss. I, 16, 21, PL. 44, 120-121). 
"Desde el instante en que comenzamos a existir en este cuerpo mortal, nunca dejamos de tender hacia la muerte. Esta es la obra de la mutabilidad durante todo el tiempo de la vida (si es que la vida debe llamarse): el tender hacia la muerte. No existe nadie que no está más cercano a la muerte después de un año que antes de él, y mañana más que hoy, y hoy más que ayer, y poco después más que ahora, y ahora poco más que antes. Porque el tiempo vivido es un pellizco dado a la vida, y diariamente disminuye lo que resta; de tal forma, que esta vida no es más que una carrera hacia la muerte. No permite a nadie detenerse o camínar más despacio, sino que todos siguen el mismo compás y se mueven con igual presteza. Efectivamente, el que tuvo una vida más corta no cruzó el tiempo con más celeridad que el que la tuvo más larga, sino que, arrancados sus momentos de igual modo a ambos, uno tuvo la meta más cercana, y el otro más alejada, meta a la que uno y otro corrían con idéntica velocidad. Una cosa es haber andado más camino, y otra haber caminado más idespacio. En consecuencia, el que hasta llegar a la muerte apura espacios más largos de tiempo, no corre más despacio, sino que anda más camino" ${ }^{28}$.

Si el pecado incidió sobre el hombre, y con él se hizo más patente la contingencia humana en la historia, y el tiempo hizo su presencia, marcando más ta transitoriedad de las horas, con todo, algo quedó que el pecado no pudo corromper en lo humano: el tiempo como señal indicadora de eternidad, y la naturaleza humana participando de la Verdad ábsoluta, con lo que se enclava, o puede enclavarse en la eternidad ${ }^{29}$. Aún el ser es la morada dell ser; y el ser reclama la perennidad para el hombre a su paso por el tiempo-historia y que hace arder en él el fuego sagrado de una inquietud a lo divino ${ }^{30}$. El tiempo, en su cualidad de ser, a pesar de su mutabilidad y desgarramiento, aún sigue en medio de una eternidad, a la que hace referencia de principio a fin. Si es ritmo o corriente hacia la muerte, por serlo, es indicador de resurrección y de vida. La eternidad lo envuelve y coexiste en él y con él; y con ello se apunta el tiempo una posibililidad de redención. Para San Agustín lo que ha cambiado no ha sido el tiempo, que sigue su andadura, sino el

28 De civit. Dei XIII, 10, PL. 41, 383.

29 ...qui eum peccantem nec impunitum esse permissit, nec sine misericordio dereliquerit (De civit. Dei V, 11, PL. 41, 153). Nisi enim bonum relictum esset, bonum amissum dolere non posset (De civit. Dei XIX, 13, 2, PL. 41, 641).

30 De Trinit. IV, 1, 2, PL. 42, 487-488. 
hombre, que ha mudado su temporalidad y la de las cosas que él usa. $\mathrm{Y}$ sólo es para el hombre esa posibilidad de redención, que se encuentra en el tiempo-historia.

El hombre se mueve en el tiempo en medio de dos tirantes, de dos dimensiones humanas ${ }^{31}$. Con una dualidad psíquica potencial, el hombre en cada acción y en cada instante se mueve por uno de estos dos amores: el de sí y el de Dios —-cariidad y egoísmo-; y a cuestas con uno de ellos, según su moido de actuar libre, camina a lo largo de su vida y a lo ancho de la historia de la humanidad. Con la aparición, por el pecado de origen, de este doble tiranté, comienza también la historiatiempo, que es mi historia y ou historia, y la de cada hombre. Así, el tiempo tiene una doble cuallidad, no en sí, sino desde el lado humano: victoria o derurota, amor o deshonor, según se inaline el hombre por el valor auténtico de sí y de lo demás, o por la deshonra de sí mismo por la incomprensión de lo atro. Con esto camina el hombre a la eternidad, - bien hace su eternidad -estancamiento culpable- en las cosas del tiempo, aunque éstas sólo le regalen lo que tienen de temporalidad, que el hombre estima como eterno.

Todo esto le da pie a San Agustín para pensar sobre el tiempo como una distensio animi, porque al quedar la humanidad sumengida en el pecado-tiempo; éste toma las características del tiempo psicológico o individual. "Y esto que acontece con la vida del hombre, de la que forman parte cada una de sus acciones, eso mismo acontece con la vida de la humanidad, de la que son parte las vidas de cada uno de los hombres" 32. Pues, si el tiempo es una distensio animi, la historia -tiempo común de la humanidad - será una distensio humanitatis a lo largo de la duración del tiempo. El tiempo histórico adquiere su sentido en una presencia suprahi'stórica, que, prescindiendo de los tiempos y dándoles origen, se instala en la historia misma para darle sentido de dirección en la profundidad del presente hacia la lejanía del porvenir. Cristo en la historia ıda comienzo, dirige, llena y culmina todo lo humano a través del tiempo, y fundamenta, explicando, toda la historia humana. Lo mismo que el hombre mide y juzga los modos diversos del tiempo con sus facultades memoria — pasado-, atención —presente- y esperanza — $\mathrm{fu}$

\footnotetext{
31 Remitimos al lector a la obra del P. R. FLórez, O. S. A.: Las dos dimensiones del hombre agustiziano, Religión y Cultura, Madrid 1958.

32 Conf. XI, 28, 38, PL. 32, 824-825.
} 
turo-, Cristo se hace presente de modo total y pleno, dando comienzo al tiempo-historia en la promesa de redención, continuándolo en su encarnación-muerte-resurrección y acabándolo en la perfección-salvación definitiva.

Cristo es un eterno presente, como Verbo del Padre, y presencia profética como Redentor en el tiempo; presencia-presente-real en el mundo hecho visible en la Encarnación, con la que, explicando el misterio de todo lo humano total, se hace efectiva la realidad de lo eterno en el tiempo, y se abre camino a la esperanza y a la realidad de lo eterno en el tiempo, y se abre camino a la esperanza y a la realidad de la mediación efectiva entre Dios y el hombre. Cristo es también presencia intencional, escatológica, por la que el futuro ya se hace tiempo presente en cada hombre para clarearse a toda la humanildad redimida al final de los tiempos, en el futuro soteriológico definitivo. Así, la historia toma su valor y su fundamentación en y desde la eternidad, ya que su desarrollo humano-temporal se hace en medio de la misma, en un punto de lo ẹterno, en donde se realizará el centromotivo-histórico con la Redención, que es la razón y la finalidad del tiempo y de la historia. Porque en tanto hay tiempo en cuanto hay historia, en cuanto hubo una esperanza de redención, una realidad de redención y una mediación del Dios-Hombre en y para la humanidadhistoria-tiempo. Cristo es siempne presente; y siendo presencia actual y actuante, El es historia divina, que se desarrolla en el tiempo-mundo desde el lado del tiempo-pecado en favor del hombre a lo largo de una santificadora mediación universal ; hasta que todo se complete histórica y temporalmente en el últitimo día ${ }^{33}$.

Esta visión cristiano-agustiniana de la histonia, siendo una visión de verticalildad $\rightarrow$ Dios hombre, hombre-Dios- no descuida la otra dimensión horizontal del hombre-esperanza: Cristo-redención, hombreredimido; sino que la incluye; y con ella rompe la oposición de eternidad-tiempo, que, con los ciclos de eterno retorno, la filosofía griega untroducía en las inteligencias, robándoles la subida a la esperanza. $\mathrm{Si}$ todo sale de Dios —creación-, si toodo se mejora en Cristo -redención-, porque se rompió la unión hombre-Dios, y si todo camina hacia Dios -mediación de Cristo y salvación del hombre-, los ciclos histó-

33. ...ultimun diem, o novissimum tempus (De civit. Dei XX, 1, 2, PL. 41, 659 ; Ibid. XVIII, 35, PL. 41, 593-596). 
ricos sobran, porque Cristo murió una sola vez ${ }^{34}$, y una sola vez fue redimido el hombre; y esto sólo basta para el plan de salvación de Dios, y es infinitamente suficiente para levanitar al hombre caído. Y porque la historia no es más que eso, historia de un plan de Dios para salvar al hombre, es historia también del hombre para aprovecharse de la salvación, que Dios le regala. Y toido a través del Mediador-Redentor, del Mesías, de Cristo-Jesús. Hay historia del hombre, porque hay un Dios-Creador, un Verbo-Encarnado, un Cristo-Redentor y un CristoMediador. Sólo por eso.

Esta concepción del tiempo y de la hilstoria supone la reposición de una nueva visión de temporalidad sobre la temporaliidad primitiva, desde el lado humano. La temporalidad primitiva medía los modos del trempo desde el plano de una realización integral ; con la temporalidad empecatada mide el hombre los modos idel tiempo, también desde el lado humano, pero con una intencionalidad a un centro único, motivo de salvación y esperanza, o prolongación de redención. Esta temporalidad -visión cósmico-temporal del hombre redimendo y redimidose instala en la historia como una donación de Dios, permaneciendo en la esperanza, que pasa a la realidad en el proyecto de salvación redentora en la Encarnación. Si el hombre pudo caer, y cayó, no pudo ya redimirse por falta de precio en el rescate. Si Dios le promete salvación-redención, ésta comienza a realizarse en el tiempo-pecado con una posible reinstalación en la temporallidad primitiva como meta y centro. Así queda ya afirmado en el epicentro humano un tiempo de cura y salvación, que se entronca ya con la eternidad. En la historia el eje será Cristo, hacia quien todo se dirije a parte ante, y de donde todo sale a parte post; y en esta parte segunida del tiempo-historia es la Iglesia el centro, como la base de salvación humana y el primer contacto con el Reino de Dios, que se comienza en el tiempo, y culmina en la eter-

34 Absit autem a recta fide, ut his Salomonis verbis illos circuitos significatos esse credamus, quibus illi putant sic eademi temporum temporaliumque rerum volumina repeti, ut, v. gr., sicut isto saeculo Plato philosophus in civitate Atheniensi, et in ea schola quae Academia dicta est, discipulos docuit, ita per innumerabilia retro saecula, multum prolixis quidem intervalis, sed tamen certis, et idem Plato eadem civitas et eadem schola iidemque discipuli repetiti et per innumerabilia deinde saecula repetendi sint: absit, inquam, ut nos ista credamus. Semel enim Christus mortuus est pro peccatis nostris; resurgens autem a mortuis iam non moritur, et mors ei ultra non dominabitur: et nos post resurrectionem semper cum Domino erimus... Satis autem istis exsistimur convenire quod sequitur, in circuitu impii ambulant: non quia per circulos quos opinantur, eorum vita recursura; sed quia talis modo est erroris eorum via, id est, falsa doctrina (De civit. Dei XII, 13, 2, PL. 41, 351-352). 
nidad. Así, en el tiempo, va tejiendo el hombre su vida, centrado en la historia del Reino.

Ahora ya, con la redención efectuada, el tiempo deja, o pueide dejar, su condición de pecado, su situación de inmadiurez, y pasar a la certeza de que una savia divina lo rejuvecene para instalarse en y para la vilda. La muerte pasó, porque fue vencida por la Vida ${ }^{35}$.

Dentro del tiempo redimido y de redención $\rightarrow$ presencia de CristoMediador-Redentor, o Cristo-Presente- el hombre camina dentro de la plenitud de los tiempos en esperanza ${ }^{36}$, o sobre ella, y siempre hacia el final. Como el hombre camina a su destino en Dios, el tiempo también thene un término en un sábado eterno, que no sólo mide los tiempos, sino que, después del final de la historia, los convertirá en el instante eterno dentro de la paz de la interminable eternidad. La historia, como la entiende el Cristianismo, es un proceso dialéctico, que dentro de sí lleva un dinamismo intencional, por el que la humanidad se va realizando en un más profundo conocimiento de sí misma, de Dios y de lo que a ella le rodea, y acercándose cada vez más a Dios, como a su meta de destino; y todo el hombre, al reallizar más su ser, queda también más cerca de su Creador ${ }^{37}$. Así, como en todo, una atmósfera de confianza y de optimismo se diluye en lo humano íntimo, y rebasa al exterior, llenando toda la historia. La Ciudad de Dios está concebida y realizada bajo este signo de alegría y confianza, sabiendo que el hombre no camina solo por la senda de la vida, porque tiene la certeza de que Dios está a su lado, y que le es más interior que lo más íntimo suyo $^{38}$, y que de este modo su vida queda convertida en gozo. La gra-

35 I Cor. 15, 55; Os. 13, 14; Heb. 2, 14. Si autem accipiamus hoc totum saeculum nocte; utique tempestas nocte clamamus ad Deum, et praevenimus maturitatem temporis in qua nobis redditurus est quod promissit, sicut alibi legitur: Praeveniamus faciem eius in confessione. Quam si velimus intelligere inmaturum tempus noctis huius, antequam venisset plenitudo temporis, id est, ipsa maturitas, quando Christus manifestaretur in carne; nec tunc Ecclesia tacuit, sed praeveniens istam maturitatem, prophetando clamavit... (En in ps. 118, 29-4, PL. 37, 1.587). $347-350$

36 De civit. Dei XVIII, 19; XX, 7, 2; 12, 1, PL. 41, 576-577, 667-668,

37 Sicut autem unius hominis, ita humani generis, quod ad Dei populum pertinet, recta eruditio per quosdam articulos temporum tanquam aeternum profecit accesibus, ut a temporalibus ad aeterna capienda et a visibilibus ad invisibilia surgeretur; ita sane ut 'etiam illo tempore quo visibilia promittebantur divinitus praemia, unus tamen colendus conmendaretur Deus, ne mens humana vel pro ipsis terrenis vitae transitoriae beneficiis cuiquam nisi vero animae Creatori ac Domino subderetur. (De civit. Dei X, 14, PL. 41, 392).

38 Conf. III, 6-11; IV, 12, 18, PL. 32, 688; 700-701. 
cia de Dios se le da en realidad de naturaleza, y hace que el hombre participe a su modo humano de la naturaleza de Dios ${ }^{39}$.

A lo largo de toda la Ciudad de Dios hay una tensión única del hombre: Dios en la historia, y el hombre realizándola con la puesta de sus acciones libres. Aún en medio de un tiempo empecatado - ciudad terrena - puede hacer el hombre que su vida discurra por un tiempo redimido - ciudad de Dios-; y todo bajo el signo vector de la Providencia de Dios. Hay una lucha entre los dos tiempos, que realizan toda la historia, como un drama, o como una conquista del hombre sobre sí y sobre lo demás.

La vida humana es un peregrinar lleno de esperanza en los ciudadanos de la civitas Dei, y transido de amargura en los de la civitas terrena. Con todo, "la eternidad ha salvado al tiempo mortal y para vivir el tiempo redimido, el tiempo de la vendadera resurrección, sólo se nos pide que vivamos el sentido de la redención merecida y donada por Cristo, que nos llama como temporales para hacernos eternos" ${ }^{40}$.

El mundo existe por un acto amoroso de Dios, y el tiempo, que acompaña al mundo en su existencia contingente, también. $Y$ sólo porque la voluntad de Dios hizo un acto de creación es porque existe el mundo en el tiempo, y éste do acompaña a lo largo y a lo ancho de la historia. Le es tan esencial el tiempo al mundo, que en su contingencia temporal es el tiempo para el mundo una necesidad ontológica.

Tanto el tiempo como la historia son horizontales, es decir, nunca se repiten; y es al Cristianismo a quien se debe esta conquista. Lo creemos todos, y lo afirma de una manera clara Henri Charles Puech: "Concebir el tiempo y la historia como serie unilateral e irrevertible, en la que los hechos vienen realmente unos tras otros, nunca se repiten, e influyen una sola vez en el desenvolvimiento, nos parece hoy la cosa más obvia... Pero de hecho es una conquista cristiana. Para la filosofía helenista el rodaje del tiempo era cíclico. Y lo era ponque la dominaba el concepto de inteligibilidad en la que el ser auténtico y pleno es sólo el Inmutable, idéntico a sí mismo, mientras que el movimiento y el suceso sólo pueden valorizarse con la permanencia perpetua mediante la repetición cíclica... Según la cólebre idefinición platónica, el tiempo que determina y mide la rotación de las esferas celestes, es la imagen movible de la inmoble eternidad, a la que imita con sus giros penpetuos.

39 Amando Deum efficimur dii... (Ser. 121, 1, PL. 38, 678).

40 P. R. Fí́́Rez, O. S. A., o. c., 185. 
Y esto vale no sólo parra el mundo físico, sino también para el generativo y humano. Pitagóricos, estoiicos y neoplatónicos convienen en admitir que en el interior de esos círculos -aiônes, aeva - se repiten las mismas situaciones ya producidas en ciclos precedentes, por ejemplo, la condena y muerte de Sócrates... Por eso, en la duración cósmica, que es anakulôssis, o perpetuo retorno, ningún punto significa principio ni fin; pues, desde la eternidad y por toda la eternidad se repiten todos; vale sólo esa repetición, reflejo del absoluto.

"De aquí que el helenismo, aunque piense de otro modo W. Nestle, no llegó a elaborar una filosofía y menos una teología de la historia. Lo único que obtuvo, y eso tardíamente con Polybio y Diodoro, fue fijar los ciclos -otra vez ciclos- de la vida política. Lo movible no tenía valor en sus elementos específicos, sino en su repetición; y si alguna vez lo concibió en modo lineal, cual ejecución el tiempo de ideales platónicos, por ejemplo, el de la ciudad, fue sólo como decadencia no como progreso de un estado primitivo (Brehien), concebido como mito. Mito que tampoco se forjó como hecho histórico inicial, sino como recurso narrativo y fantástico...

"El Nuevo Testamento, en cambio, como do ha demostrado Cullman, da valor lineal y sentido propio a los hechos históricos. Su curso tiene un principio - real- en el Génesis y un fin -efectivo- en el Apocalipsis; y al abrazar toda la humanidad, da valor a cada persona que, por encima de los ciclos eternos, es libre ante Dios, y ordena unos hechos a otros en la economía de un Verbo Providencial. De un Verbo que interviene en sus fases, preparando su propia venida, y que se encarga luego y se resucita para dar nacimiento a los tiempos nuevos" ${ }^{41}$.

San Agustín no admite una prioridad' eternamente discurrente para la historia; no puede hacerlo, porque lo contrario sería una irrisión, un ludibrio y una destrucción del dogma cristiano, que él quiere ver desplegándose en $\mathbb{l a}^{2}$ historia ${ }^{42}$. Hay sí un avance, una ley del ser y de la evolución; pero nunca es repetición, sino un progreso lineal e intencional ${ }^{43}$. Frente a este retorno eterno él proclama e introduce por primera vez en el pensamiento humano el iter rectum, que lleva a Dios por medio de su Verbo, con su preparación-promesa y su cumplimien-

\footnotetext{
41 J. Ch. PUECH, Temps, histoire et mythe dans le Christianisme des premieres siécles; Proceedings of the 7th Congress for the History of Religions; Amsterdam 4 th-9, September 1950 (Amsterdam 1951), pp. 33-38.

42 De civit. Dei XII, caps. 13 y 20, PL. 41, 360-362 y 369-372.

43 Ibid. XII-XII, PL. 41, 360-362.
} 
to-Cristo. Jesús, novedad cristiana, se enfrenta a la eternidad monótona del griego, y esta novedad no puede repetirse. Frente a la desesperación, que engendra la no-esperanza del ciolo eterno en penpetuo suceder y repetirse, la felicidad tranquila del cristianismo, que rompió los eslabones de esta cadena con la ayuda del Señor en su revelación, puede decir con San Agustín: "Nosotros no poidemos creer esas cosas. Cristo murió una sola vez por nuestros pecados" 44 y bastó para la redención de la humanidad.

La teoría del conocimiento le sirve a San Agustín para argumentar contra los platónicos. Hay dos caminos a la verdad: uno, de la Sabiduría, que engendra verdad-certeza; el otro, el de la opinión, que sólo da parecer subjetivo, y casi nunca certeza. La Sabiduría, para San Agustín, es el reflejo de lo inmutable, lo que siempre vale y nunca se altera; la opinión $\multimap d o x a-$ se va por los vericuetos de lo humano, que es mudable y contingente. Siendo el hombre plena contingencia, sus quehacenes están atravesados de esta misma cualidad.' Luego al hombre y a sus obras los traspasa una razón de transitoriedad íntima, por lo que todo lo suyo es de tal moido partioular, que con nada ni con nadie se puede confundir. Su historia, particularmente suya, no se confunde con la historia de otros hombres, ni con la de otras épocas: es suya plenamente; y, como suya, irrepetible. Su tiempo de es tan particular y propio, que el tiempo de los otros hombres, pasados o futuros, no le pertenece. A él sólo le corresponde una propiedad individual : su presente, su particular pasado y su esperanza de futuro. El tiempo y la historia le son tan suyos, que nadie puede apropiárselo.

Le es posible al hombre sublimarse a la contemplación de la Sabiduría, irrepetiblemente una y única para todos. Esta Sabiduría, identificada con el Logos del Padre, con el Verbo, con Cristo, tiene en Sí la plenitud de la ciencia humana, que toma de El el fundamento de ser y de ser verdad. Por la que la contemplación del Verbo, siendo la única Sabiduría, a ella se subordinan las demás verdades, las ciencias de lo contingente y transitorio, a las que la historia se une y de las que forma parte. Por otro lado, el Verbo, al hacerse hombre, y saltando al tiempo, y constituyéndose centro de la historia, reúne en Sí sabiduría y ciencia, y todo para que la ciencia de su vida y doctrina en el tiempo sea la que

44 De civit, Dei, XII-XIII, PL. 41, 360-362, 
nos alimente y nutra de fe, y nos lleve a la contemplación de la Verdad Eterna ${ }^{45}$.

La vida de Cristo, o Cristo mismo, es divinización del tiempo, o redención del tiempo-pecado para conseguir un tiempo-historia de salvación. Por eso, la vida del Mediador-Redentor no se limita a los treinta y tres años de Belén-Calvario, sino que se dilata y perpetúa, actuando el Cuerpo Místico-Iglesia, pueblo de Dios, objeto supereminente en la concepción progresivo-lineal de la interpretación de la historia por San Agustín ${ }^{46}$. La profecía misma es una dirección lineal y dinecta del suceso futuro. Todo el Antiguo Testamento está cargado de esta economía divina, o intencionalidad histórica en su finalidad de salvación-redención ${ }^{47}$. En toda la historia hay una mano discreta, que empuja y acrecienta de sentido todo lo humano en su acontecer histórico. Todo suceso tiene su lugar y tiempo - su finalidad-y lo que sigue es consecuencia de un preceder, que influye en lo que luego sucederá. En el tiempo y por el tiempo se cumple el plan divino -economía - un desarrollo providencial, que, afluyendo todo a la Encarnación del Verbo, luego que se realiza en el tiempo-historia la venida de Cristo, todo arranca de El para llevarlo a la gran socialización divina en la parusía del Señor. Este es el sentido de la intencionalidad histórica, sentido de dirección, la finalidad y la explicación divino-humana de la presencia del hombre en el espacio-tiempo-historia.

San Agustín, tomando la Histonia Sagrada como punto de partida, aplica los mismos principios a la historia universal de los pueblos y en

45 Mens autem rationalis sicut purgata contemplatione debet rebus aeternis; sic purganda, temporalibus fidem... Nunc ergo adhibeamus fidem rebus temporaliter gestis propter nos, et per ipsam mundamur; ut cum ad speciem venerimus, quemadmodum succedit fidei veritas, ita mortalitate succedat aeternitas... Quod donec fiat ut fiat..., ipsa Veritas Patri coaeterna de terra orta est, cum Filius Dei sic venit ut fieret filius hominis, et ipse in se exciperet fidem nostram, qua nos perduceret ad veritatem suam, aui sic suscepit mortalitatem nostram, ut non amitteret aeternitatem suam (De Trinit. IV, 18, 24, PL. 42, 904). Scientia ergo nostra Christus est, sapientia quoque nostra idem Christus est. Ipse nobis fidem de rebus temporalibus inserit, ipse de sempiternis exhibet veritatem. Per ipsum pergimus ad ipsum, tendimus per scientiam ad sapientiam: ab uno tamen eodemaue Christo non recedimus, in quo sunt omnes thesauri sapientiae et scientiae absconditi (Ibid., XIII, 19, 24, PL. 42, 1.034).

46 Nam in illo (en Cristo-Hombre) et Ecclesia suscepta est a Verbo (En. in ps. 4, 9, PL. 36, 82-83)... sponsus per personam sponsae loquitur... Christum. intelligimus et Ecclesiam... Ecclesia in illo patiebatur ipse, quando pro Ecclesia patiebatur; sicut in Ecclesia patiebatur ipse, quando pro Ecclesia patiebatur (Ser. 140, 8, PL. 38, 767-768).

47 Intelligis... in ipsis etiam promissionibus, te (Ecclesiam) iam tunc figuratam et prophetatam, praescientiam parturisse sanctorum (Contr. Faust. 15, 4, PL, 42, 305). 
cada pueblo. Si tiene historia Israel, la tiene en función y sólo por el Mesías. Es decir, todo el hombre, siendo fondo de pecado, es motivo de salvación; y sólo en orden a la salvación está en el mundo, se constituye en persona y realiza la historia. En la disputa que entabla con Porfirio, San Agustín se agranda, planteando esta dirección lineal salvífica en la historia de la humanidad. Porfirio, acérrimo neoplatónico, discípulo predillecto de Plotino, a quien el Santo arguye de ilógico, porque rechazando los ciclos eternos históricos, admite la metempsicosis -un ciclo repetible para las almas pecadoras-, se aferra a la opinión de Plotino, dando máxima importancia a los hechos contingentes, no deducibles de la filosofía y aún contrarios a ella como la resurrección de los santos y de Cristo ${ }^{48}$. ¿Es posible subordinar a la vendadera sabiduría - filosofía - un hecho cósmico, en el que los sucesos básicos no imitan en nada ni encarnan las razones eternas? La historia no se realiza ipor deducciones filosóficas, o por imposicioneș científicas; es realización de actos humanos, que dependen únicamente de la libre determinación de la voluntad ${ }^{49}$. La historia, como ciencia positiva, nos proporciona hechos realizados y comprobables; un objeto formal, no sólo desde el campo estricto de inteligibilildad, sino desde la ciencia empírica, como experimentalmente autónomo, y, como el de cualquier ciencia, dependiente en su orto y progreso del ritmo de todo ser en su principio $v$ en su finalidad, de Dios; pero no sólo por esas razones inmutables y necesarias, sino de dos concausas: del libre albedrío de la voluntad

48 De civit. Dei XII, 20, 3, PL. 41, 370-371.

49 Quasi vero, quia praecelsam incomutabilemque substamtiam per illa quae facta sunt intelligere potuerunt, proptera de conversione rerum mutabilium. aut de contexto saeculorum ordine consulendi sint. Numquid enim quia verissime disputant. et documentis certissimis persuadent, aeternis rationibus omnia tem. poralia fieri, propterea potuerunt in ipsis rationibus perspicere, vel ex ipsis colligere exordiis, qui modus in incrementis, qui numeri per conceptus, per ortus, ner aetates, per occasus, aui motus in appetendis quae secundum naturam sunt, fugendisque contrariis? Nonne ista omnia, non per illam incommutabilem sapientiam, sed per locorum ac temporum historiam quaesierunt, et ab illis experta atque conscripta crediderunt?

Quo minus mirandum est, nullo modo eos potuisse prolixiorum saeculorum seriem vestigare, et quamdam metam huius excursus, quo tannuam fluvio genus decurrit humanum, atque inde conversionem ad suum cuiaue dehitum terminum. Ista enim nec historice scribere potuerunt longe futura et a nullo experta atque narrata.

Nec isti philosophi ceteris meliores in illis summis aeternisque rationibus intellectu talia contemplati sunt: alioquin non eiusdem generis praeterita quae potuerunt historici inquirerent. sed potius et futura praenoscerent auod aui intuerunt. ab eis vates, a nostris prophetae ancllati sunt (De Trinit. IV, 16, 21, PI. 42. 902), 
humana y de la benéfica disposición de la Providencia de Dios, que se nos revela en cada momento y a cada paso ${ }^{\text {b0 }}$.

San Agustín busca para la historia un ecumenismo de pensamiento y de sentimiento. No le basta el ecumenismo de la fe católica; quiere también un origen común para los hombres y para los hechos de los hombres, para la historia. Por eso, no pone el origen de la historia en el inicio del Imperio Romano $-a b$ urbe condita-, ni en Nino, el supuesto fundador del Imperio Babilónico, ni en la aparición de la escrituna o vestigios de ella. Agustín busca el origen para la historia en la creación del hombre, y como si quisiera para ella también un entronque en la creación de los ángeles. Los imperios terrenos no le sirven para su orto histórico, porque, engendrados en robos y fratricidios, no es bueno colocar ahí el origen de la salvación humana, para el centro-resumen de la creación, para el hombre ${ }^{51}$. No le gusta el universalismo de Roma, funidado en la guerra y amasado con sangre de hermanos. Reconoció, es verdad, los grandes aportes humanos traídos al mundo por la pax romana; pero él quería y buscaba en la historia unos orígenes comunes y la realización de una sociedad universal, que, fundándose en el amor, no se confundiera con los límites-tiempo de unas legiones o de unas falanges, y no le gustaba que se llamara bárbaros o extraños a los pueblos de fuera de los idominios de Roma y Babilonia. Agustín busca el origen para la historia en el arranque mismo del tiempo humar no y en el comienzo de la existencia del hombre sobre la tierra, porque allí ve a Dios y ve al hombre, los dos actores coautores del acontecer de todas las edades históricas. Además, y no disminuye esto en importancia, veía en ese su ecumenismo el comienzo universal del Reino de Dios, de la Ciudad de Dios. Por esto, las historias particulares de los imperios del mundo casi no le interesan; para él sólo es importante la bistoria de la salvación del hombre, desde el principio-creación al finsegunda-venida de Cristo. Y, por lo mismo, la Historia Sagrada del Antiguo Testamento cobra en San Agustín capital importancia, porque es la historia de todos y para todos. Será en esta historia salvífica en donde se va realizando el concepto profundo de esa saciedad universal,

50 Quoniam igitur divina Providentia, non solun singulis hominibus quasi privatim, sed universo generi humano tanquam publice consulit; quid cum singulis agatur, Deus qui agit atque ipsi cum quibus agitur sciunt. Quid autem agatur cum genere humano, per historiam commendari voluit, et per prophetiam (De ver. Relig. XXV, 46, PL. 34, 142).

51 Felicioribus rebus humanis, omnia regna parva essent, ut sunt in urbe comus plurimae civium (De civit. Dei IV, 15, PL. 41, 124). 
soñada por él, y que mucho más tarde y con muy claro acierto Teilhard de Chardin llamó socialización divina del hombre, en donde se adorará a Dios con amor y fe no fingida. Esta sociedad no es unidad de sumisión de esclavos, sino concordia amorosa de voluntades, que llevan a la unidad ecuménica y a la universal obediencia racional.

No obstante su concepto amoroso de romanidad es claro y abierto; pero nunca creyó en su perpetuidad como la quiere para su ciudad de Dios. A pesar del reconocimiento al mérito y virtudes del Imperio Romano ${ }^{52}$, Agustín se lanza a la historia de un reino perpetuo, que teniendo su principio y desarrollo en la tierra, se realizará plenamente después del tiempo-historia. Ese Reino de Dios es comenzado en la Iglesia, que tuvo su prtólogo en la historia de Israel. Todos los otros imperios y reinos pasarán con el tiempo, aún los que Dios escogió para Sí como porción predillecta ${ }^{53}$.

B.-Los ciclos cósmicos tDe La filosofía gRIEga : Refutación cRistianoAGUSTINIANA.

Es una cosa cierta que en casi todas las religiones paganas de antes de Cristo la metempsicosis era una especie de dogma común a todas ellas. Aparte ide otras interpretaciones - biológica, filosófica, teológica...-, a nosotros nos interesa bajo el punto de reiteración histórica: en cada reencarnación el hombre dejaría señal de su paso por el mundo, de ser cierta la posición bio-reiterativa en el hombre.

San Agustín no puede admitir esta reencarnación, o serie de reencarnaciones sucesivas, ni la repetición del tiempo histórico, porque Cristo - centro de la historia - ha muerto una sola ve ${ }^{54}$, y ha sido infinitamente suficiente la redención que nos ganó con su sangre. Además, no hay prueba ninguna en la historia que avale la metempsicosis. Tampoco

52 Deus enim sic ostendit in opulentissimo et praeclaro imperio Romanorum quantum valerent civiles, etiam sine vera religione, virtutes; ut intelligatur, hac addita, fieri homines cives alterius civitatis, cuius rex veritas, cuius lex caritas, cuius modus aeternitas (Epist. 138, 3, 17, PI. 534).

53. Quid expavescis quia pereunt regna terrena? Ideo tibi celeste promissum est, nec cura terrenis perires (Ser. 105, 9. PL. 38, 622). Transiet quae fecit ipse Deus; quanto citius quod condidit Romulus (Ser. 105, 10. PL. 38. 623). Adhuc enim habet auo crescat, donec fiat quod de Cristo in Salomonis figura dictum est: Dominabitur a mare usaue ad mare, et a flumine usque ad terminos orbis terrae (Epist. 199, 47. PL. 33, 922).

54 De civit. Dei XII, 13, 2, PL, 41, 361-362. 
es admisible por parte de la salvación del hombre; cada uno es responsable de sus actos en el tiempo de mérito, y no se da más que el que toca vivir a cada uno sobre la tierra. No obstante, todas estas creencias reiterativas son dignas de tener en cuenta por el afán de supervivencia más allá de la muerte, y todas son expresión del ansia humana de inmortalidad. Grecia, por ejemplo, hizo suya esta doctrina, amasándolla en las escuelas filosóficas para que el pueblo tuviera un motivo definible de vida con el mito del retorno eterno, que es para el griego un sentimiento del presente constante, y que da significación a toda la Hélade desde Homero, Herádito y Pitágoras hasta Proclo y los últimos filósofos de Atenas.

Los jónicos hablaron de un z̈rвipov, como tiempo de lo ilimitado, una confusión de masa infinita, de donde todo emerge, como a empujones, para formar el mundo y regresar al cabo de un determinado tiempo,

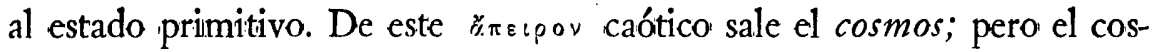

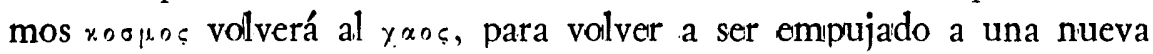
salida, y así eternamente. Heráclito, si a primera vista parece oponerse a este curso y recurso con su $\pi$ avi $\alpha$ $\oint_{\varepsilon} \check{i}$, con ella afirma esta reiteración universal. Para él hay un período de un año gigante - $\mathrm{r} .800$ años solares--, a cuyo final habrá una conflagración universal, volviendo todo al fuego, de donde salió, para aparecer nuevamente todo, y vivir otro año grande, regresar al fuego y volver a aparecer. Así eternamente. Bien conocida es la imagen del mundo en Platón, como una especie de figura móvil de eternidad, que, con movimiento circular perpetuo, remedando un modelo viviente conforme al que fue creado, aparece y desaparece constantemente. Aristóteles habla también de un retornar constante, y no ve inconveniente en aue la guerra de Troya se repita infinitas veces. Las apariciones de los hombres —según él- se repiten infinidad de veces. También los estoicos admitían esta doctrina cíclica. Así, concluído el número determinado de fenómenos y posiciones de cada astro en un ciclo, el éter, desde la última esfera aumentará su tensión; un incendio voraz acabará con lo existente, convirtiéndolo todo en éter, o en el estado primitivo. A este cataclismo sólo sobrevivirá Dios, fuego infinito y eterno. De este fuego, potencia creadora, otra vez saldrá el cosmos a cumplir con la existencia de un ciclo temporal más ${ }^{55}$.

Un fatalismo determinista reinaba en estos circuitos, influyendo en

65 Es interesante sobre este punto Nemesio de Siria: De natura hominis, 48; Orígenes: Contr. Celsum V, 21; San Agustín: De civit. Dei VIII, 12, XII, 13, PL. 41, 236, 360-362; Cicerón; De natura deorum II, 20. 
todo. El mundo de los astros gobierna el de la tierra; y una prueba de esta creencia fue la astrología, tan en boga por los tiempos inmediatamente anteriores y coetáneos a San Agustín. En el movimiento circular r an rodando también los hombres. Salvo raras excepciones entre griegos y romanos, todos dieron asentimiento a este determinismo universal; y los más aferrados a estas doctrinas fueron los estoicos. Tanto, que para Crisipo el hado todo lo invade como "una sucesión eterna e invariable de las cosas, una cadena que da vueltas y arrastra un onden fijo de consecuencias, con que está dispuesta y enlazada" "56. En este determinismo nada tiene que hacer la voluntad humana con su don de libertad, porque es "como un cilindro —palabras de Crisipo - que el destino lanza por una pendiente continua, rodando en virtud' de su forma y peso" 57 . Los hados - dice Séneca- nos llevan y traen y disponen todo lo nuestro ${ }^{58}$. Por eso, cuando un hombre entra en la vida, la hora fatalis lo toma en sus brazos, y no lo abandona hasta el sepulcro.

El fatum para Plutarco es un cínculo en que, inmerso el hombre, haga lo que haga, no puede salirse de su influencia anillar: "Todas las cosas, ora en la revolución completa, ora en la de cada totalidad, volverán del mismo modo. Luego cosa manifiesta es que el hado, en cierto modo infinito, no lo es, y así se pudo ver bien que es cierto círculo. Y pues el movimiento circular y el tiempo debe considerarse la misma razón de todas las cosas que se hacen" ${ }^{59}$.

$\mathrm{Si}$ todo estaba predeterminado por ese hado, que parece ser era un movimiento o suceder constante de seres y de acciones de ser, lógico es concluir que su predicción era segura. La astrología trataba de este asunto, y estaba muy del día, como dijimos, en tiempo de San Agustín y anteriormente a él. Posidonio -fatalium siderum assertor- da unas normas precisas para un buen horóscopo ${ }^{60}$. Para todo acto, que se ha de realizar, se ha de escoger el día, porque la posición de los astros, que es diferente en los diversos momentos de su duración, domina a todos los cuerpos terrenos, sean animados o inanimados. Los astros señalan con su situación celeste la realización de los actos humanos con una posición sideral determinada. Si a todo acto humano le conresponde una fijación temporal por la situación de una constelación, como estas situaciones

\footnotetext{
56 Aulo Gelio: Noctium atticarum, IV, 2 ; VII, 2.

57 Ibid., VII, 2.

58 Séneca: De providentia, V.

59 Plutarco: De fato, I, 688.

60 De civit. Dei V, 2 ; V, 7, PL. 41, 142-143; 146-147.
} 
estelares, son constantes y uniformes para cada ciclo cósmico, es lógico tratar de investigar el futuro por el horóscopo del astrólogo. En los astros - piensa Posidonio- hay unas como letras escritas para siempre, en donde están cifrados todos los sucesos futuros; pero sólo los hombres divinos pueden alcanzar el lenguaje y sentido de interpretación de estos signos. Así, por las calles y plazas de Grecia y por las de todo el Imperio Romano pululaba la peste de estos brujos. "Cuanto más se avanza en la historia de la civilización griega - dice Tigher-, más rigor y precisión adquiere la doctrina del retorno eterno, y el yugo del destino carga más sobre las espaldas del hombre. Después de los estoicos, las doctrinas de la predestinación y del hado astral y las supersticiones astrológicas invaden toda la antigüedad" 61.

Gran trabajo costó al Cristianismo desterrar de las conciencias estas supersticiones antihumanas. San Agustín, aprendiz en un principio de ellas, las combate afirmando su posición frente a los astros, seres que por lo lejanos, nada influyen en la conducta de los hombres, desterrando así la creencia en ellos como: en seres divinos ${ }^{62}$."Vemos que las estaciones del año cambian según la posición del sol, y que con los crecientes y menguantes lunares aumentan o disminuyen ciento número de cosas; pero los deseos idel ánimo no están subondinados a las posiciones siderales" 63. Es decir, si algunos de los fenómenos de la naturaleza tienen influencia sobre la tierra, el hombre está muy por encima del sucederse y de las revoluciones siderales, ponque, aunque asentado en uno de los astros, únicamente su libertad es la dueña de su voluntad.

La Ciudad de Dios, contraria a estos ciclos cósmicos, al rechazarlos, fundamenta la libertad humana, y todla la persona y el ser del hombre con una visión espiritualista. Salvando el valor de la acción humana, abre la puerta al progreso en todo orden de cosas para el hombre. No es suficiente destruir. Lo principal no es eso, sino dar en la refutación una fundamentación de la racionalidad de la persona. Si se ha anulado una concepción humana sobre el cosmos, es necesaria una ideología que la supla y agote la anterior. Por eso, San Agustín no se limitó a la crítica de la astrología pagana, sino que regaló al mundo una idea acertada y

61 TIGHeRI, La visione greca della vita, Roma 1926, 34.

62 Conf. IV, 3, 4, PL. 32, 694-695; De civit. Dei V, 5 y 6, PL. 41, 144-146; De doctr. christ. II, 21, 32; 22, 23; 23, 35, PL. 34, 51; 51-52; 52-53: In Ionn. Evang. VIII, 10, PL. 35, 1.456-1.457; Serm. 87, 11, PL. 38, 537-538; De gen. ad litt. II, 17, 35, PL. 34, 278; Contra duas epist. pelag. II, 5, 10, PL. 44, 577-578. ${ }_{63}$ De civit. Dei V, 6, PL. 41, 146 , 
segura sobre da personalidad en sus dos obras de Las Confesiones y de La Ciudad de Dios.

Si él se colocó en la encrucijada de un mundo viejo y otro nuevo, y si declaró en crisis el pensamiento pagano, fue porque él tuvo una visión más acertada del cosmos y de sus moradores los hombres. Se dio cuenta de que este retorno universal y eterno no le explicaba el inicio, el medio y el fin de la humanidad. Y sobre esta nulidad construye su tesis de la creación-redención-salvación-parusía del Señor, todo como un anuncio humano-divino de salvación para da humanidad. La revelación - -principio de autoridad - le aseguró a él la senda para caminar en la sluminación de la fe cristiana. Y se dio muy mucha cuenta de que cuando falta este rodrigón firme de la fe, se explica que, sabios, como Platón y Aristóteles, se plegaron a una ideología que no ofrece prueba experimental, y que para ellos respondía a una exigencia de su pensamiento cosmológico y teológico. La posición cristiana de creación-redenciónparusía dell Señor es el centro del cristianismo y su nervio más fuerte y seguro. Y quien lo desconoce, o conociéndolo, no camina en él, ése no es cristiano, es sólo un hombre que se desbarranca como lo hacen todos los que siguen las teorías modernas, que tratan de renovar el retorno eterno de movimiento sin meta - teología de la muerte de Dios, o teología del vacío-, de aspiración sin satisfacción, de camino sin llegada.

Los paganos no pudieron llegar al comienzo absoluto de las cosas; y proclamaron por eso, la eternidad del mundo, como un motor inmóvil -Aristóteles-, engendrando un movilimiento eterno en un universo también eterno. Afirmar lo contrario sería para ellos la negación rotunda de un Dios existente, porque un origen temporal para el mundo equivaldría a una alteración profunda en el ser y hasta en la voluntad de la primera causa. "Si se admiten los ciclos, en los que se repiten siempre las mismas cosas temporales, sea permaneciendo en el mundo, sea enredando él en esos circuitos sus nacimientos revolubles y sus acasos, no se atribuye a Dios ni un ocio apocado, máxime de tan larga duración, sin principio, ni una imprevista temeridad en sus obras. Porque si no se repiten siempre las mismas cosas, no pueden ser comprendidas esas cosas infinitas de diversidad varia por su ciencia o presencia.

"Si la razón no es capaz de refutar estos argumentos con los que los impíos se afanan por desviar nuestra piedad sencilla del camino recto para que caminemos al retortero con ellos, al menos $\mathrm{da}$ fe debe desdeñarlos. Una prueba manifiesta, que viene como a reforzar la fe del Señor 
Dios nuestro, da al traste con esos círculos fingidos por la imaginación de ellos. Su error radica en que prefieren andar en circuitos falsos a seguir el camino recto, porque miden la mente divina, absolutamente inmutable e infinita y capaz de numerar todas las cosas innumerables sin cambiar de pensamiento, por la suya humana, mudable y limitada. Y, claro está, les sucede lo que dice el Apóstol: Comparándose a sí mismos consigo mismos, no entienden (2 Cor IO, I2). Porque ellos cualquier cosa que les viene a la mente la hacen con nuevo consejo (son portadores de mentes mudables); sin duda, pensando no en Dios, en quien no pueden pensar, sino a sí mismos en su lugar, se comparan no a $\mathrm{El}$, sino a sí mismos, y no con El, sino consigo mismos. A nosotros, sin embargo, no nos permite nuestra fe creer que Dios sea afectado de una manera cuando no obra y de otra cuando obra, porque de El no debe decirse que sea afectado, en el sentido de que en su naturaleza se produzca algo que antes no había existido. En efecto, ser afectado, es padecer, y padecer es ser mudable. Por consiguiente, no se imagine en el reposo de Dios pereza, desidia o inercia; ni en sus obras, trabajo, esfuerzo o industria. Sabe obrar en reposo y reposar en obras. Puede hacer una nueva obra sin nuevo consejo, sólo con el eterno, y cuando pone manos a la obra, no es porque se arrepiente de su primer reposo. Mas si primero estuvo en reposo y luego obró — no sé cómo podrá entender el hombre esto-, dicho así primero y luego, es indudable que dice relación a las cosas primero inexistentes y luego existentes. Pero en Dios la voluntad subsiguiente no cambia o destruye la voluuntad precedente, sino que su misma voluntad, eterna e inmutable, hizo que las cosas creadas primero, en tanto que fueron, no fueran, y que luego, cuando comenzaron a ser, fueran. Quizá con eso mostraba admirablemente a los capacitados para entender tales lecciones que no tenía necesidad de las criaturas, sino que las creó por pura bondad, puesto que sin ellas, desde una eternidad sin principio, gozó de una felicidad sin mengua" ${ }^{44}$.

Hay que comprender bien lo que el griego entiende por hado-fatum. Dice, fervoroso, el estoico: Fata volentem ducunt, nolentem trahunt, que otros tradujeron así: ser sabio significa querer lo que sucede y no que sucede lo que se quiere. La libertad para el griego queda definida en función a una necesidad, o a una imposición externa en contraposición de un dato, quedándole sólo al hombre la sumisión a esa Necesidad

64 Te civit. Hei XII, 17, 1-2, PI. 41, 366-367. 
imperiosa, como a una fuerza arrolladora, que domina y gobierna el universo, la voluntad de los hombres y hasta la die los dioses. La libertad sería una desesperada aceptación, o una ineficaz rebelión, al hado, porque el hombre es inferior a él y porque tiene consciencia de serlo. Sometiéndose al hado, se hace víctima sacrificada, siempre; se someta o se rebele, siempre el hado le impondrá el acontecimiento. Luego, sólo le queda una posibilidad de redención por el sometimiento humilde en sentimiento del acontecer; es decir, hacer propia la imposición del hado. Con esto el hombre encontrará la calma en la apathía, serenidad del alma. Colocada la voluntad humana frente al hado, una densidad oscura y religiosa pesa sobre el ser humano en lo político-social, en lo psicológico y en lo ético-moral; y esto es confusión de la teología y de la cosmología. $\mathrm{Y}$ aquí es donde abunda la mayor dificultad de la filosofía griega y romana para captar el verdadero valor y contenido de la libertad, porque carecen de una noción clara de la persona y de la personalidad. Y todo, porque un naturalismo cósmico se lo impide.

Si consideramos la libertad en función a un dato, como algo externo, se la puede entender desde el plano epistemológico; porque el orden cósmico es inmutable e invariablemente dado. Por eso, a Platón no le preocupa el problema de la libertad; y Aristóteles sólo lo trata desde el lado de lo utilitario: no hay libertad, ni libre albedrío, sino sólo conocimiento y aceptación irrevocable, o rebelión inútil, hacia el orden cósmico inmutable. El hombre es libre cuando vive en armonía con el todo y no cuando es esclavo de la pasión baja, que es cuando trata de oponerse al destino. Mal y dolor entran dentro del orden universal, que rige los destinos humanos. Se es libre, cuando se conocen las leyes de la necesidad y se sabe querer en armonía con ellas. La voluntad de dominio sobre las pasiones, ésa sería la libertad para el helénico, o un vivir conforme a cuenta y razón, por un lado; $y$, por otro, un seguir la necesidad del orden cósmico. Es sabio quien según cuenta y razón quiere y anda según naturaleza.

Si todo está determinado en un orden cósmico, el acto humano de aceptación también está ya incluído en la determinación eterna, y no puede darse un querer de modo distinto al que se quiere, porque sería una incongruencia. Con todo, este acto de voluntad en la razón universal tiene correspondencia a una exigencia natural de afirmación propia en doble dirección: como querer sólo en el ortden racional de modo contrario a lo determinado y de querer sólo ese orden de razón univer- 
sal, identificándose con él, casi en la identificación de la voluntad con la perfección divina, que es a lo que está ondenado el hombre, especialmente el sabio. Puesta la voluntad humana frente al destino-hado, se convierte en el centro de acción, aceptándolo con energía, y así se hace renuncia y ecuación con lo determinado. Pero cuando no hay esa renuncia fervorosa y ecuación ecuánime, el suicidio-rebelión es una consecuencia inevitable en una compostura como ésta, toda ella vaciedad y sin sentido humano de vida-existencia. La necesidad contemplativa de Plotino se poidría identificar casi con la imperturbabilidad estoica, siendo para Plotino do patente en la acción humana una racional conquista del querer como libertad, o una puesta de la voluntad fuera de la necesidad cósmica. La libertad para él es necesidad de identificación por elevación al Nous en la esfera de lo Uno, y allí anularse, confunidirse, diluyéndose en el Todo-Uno y en ell Uno-Todo, como en el solo poder que todo lo engendra y todo lo asume.

La libertad para el greco-romano, colocada frente a un términodestino es una paradoja de libertad; porque, como el escogimiento no puede nunca dejar de colocarse en el hado, no por una fuerza exterior o extnaña, sino por una energía de desde dentro a la esencia de ese escogimiento, por esta razón la libertad queda muy mal parada. Pero si querer es escoger, se excluye toda otra posibilidad en la decisión del quiero, que es ir el hombre hasta el fondo sin vacilaciones, derecho y con firmeza. Una libertad así es bloqueo del querer; porque, como fatalidad impuesta, avanza el hombire sin libertad, como obús salido del cañón, sólo con una dirección, que le fijó un punto de mira al que se dirige ya irracionalmente. Es la libertadi esencia para lo esencial, una pequeña libertad, paradoja de lo libre, que, frente al objetivo, ya no hay posibilidad de elección. Esta es la posición del fanático, que toma como victoria la acción sobre la indecisión.

Otra es la del apóstol verdadero, del consciente de su misión, que elige y escoge una situación humana, no como una situación-límite, sino como voluntad ide amor y de humildad, porque todo lo asume con amor y lo deja con el mismo amor. La voluntad, como pasión de sí misma, realizará actos extraondinarios, porque todo lo quiere someter a sí misma; pero nunca será capaz de actuar en el heroísmo, porque los actos heroicos se hacen únicamente con amor, y el amor no tiene cabida en esa fatal necesidad de la libertad absoluta. Esta voluntad es el grito de Satán -non serviam, similis ero Altissimo!-, o el de Adán - sicut 
dii-, que quiere disfrutar de todo y a pesar de todo. Este pensamiento diabólico de absolutez ata y nunca redime, y es idonde la libertad importa menos que la absolutez.

La voluntad de servicio es una voluntad de amor, y una perfección de la libertad, porque hace moverse al hombre dentro de su racionalidad. Todos sabemos que el amor procede ciegamente hacia lo que la inteligencia le presenta como bondad y como verdad. Colocada la voluntad frente al ser-bien-verdad, no puede quedarse en la indiferencia; se lanza con impetuosidad hacia el ser, porque es el ser en razón de verdad-bien lo que le atrae y perfecciona. ¿Hay aquí libertad? Podemos decir que, en cierto modo, también la voluntad de amor procede con la fatalidad propia de su cualidad racional en onden al escogimiento por servicio al ser; del valor depende y de él se informa. Cuando entra toda en el ser, objetivándose, encuentra su lugar apropiado, en él se mueve y en él se perfecciona. Siguiendo la verdad bien-ser-objetivo, no admite otra elección, porque sería salirse de su campo peculliar y esencial, en donde encuentra su peculiar desarrollo; y, significando al bien, no admite otro cscogimiento, porque no puede hacerlo. Es su vocación, iniciativa y permanencia en el ser y para el ser; y sólo así obra en la irreductible ineluctabilidad del destino, porrque esa es su vocación-misión. Por eso, no puede la libertad ser más que la volluntad de amor en el grado de ser. Desde esta cima del ser humano recobra toda la plenitud del valer dentro del tiempo y identro del campo propio de su finitud, en la verdad del ser por y para el Ser-Dios.

Así, el apóstol es el más libre, ponque, presentándose con su voluntad aferrada al Ser por la fe, y, siendo prisionero de su ideal-ser-verdadbien, es el que más cerca está ide la perfeación, cuando su ideal radica en el ser-bien-verdad; de lo contrario, se encadena él y encadena su libertad al grillete de la pasión. El apóstoll no domina a los demás. Puesto en el servicio de bien-verdad-ser, sirve ese ser-bien-verdad a los demás con voluntad de amor. El apóstol, por amante, no es fanático. Dentro de él arde la lumbre de la verdad; y esa vendad le obliga a darse él mismo en forma de bien a los otros, a quienes ama con caridad profunda en el Ser; y respeta todo el ámbito de la libertad en el otro. No entra en él; pero siempre está, insinuándose, en proximidad, con discreción, ayudando únicamente a la disponibilidad ajena. El apóstol no tiene secuaces, esclavos de sí mismo, sino fieles, que, por serlo, actuarán siempre en libertad, aún siguiendo al apóstol. Su seguimiento también es un servicio 
$\epsilon n$, de y a la verdad; y, como servicio, siempre voluntario y amoroso. La pasión no anda nunca con la libertad; camina por la fuerza enervante y esclavizante de la declinación del bien o de la vendad, o mejor, de ambos a la vez.

Así se complrende mejor la autoridad de quien se siente libre, y que tu ata de comunicar esa misma libertad al hermano, y no al esclavo. Porque cada persona es sagrada en su voluntad; y, como sagrada, inviolable; y, por ser inviolable, digna de aprecio y consideración profunda. La confianza en los demás sólo la da la libertad, que se asienta en el ser-bien-verdad, y que se sostiene en la Providencia y en la Gracia, cuando nosottros no podemos alcianzar muchas veces la cuenta y razón de algo superior a nosotros, seguros de que cualquier cosa que pueda acontecernos, todo nuestro porvenir, no nos es mero suceso, sino signo superior de que Alguien vela por nosotros, y que nos ayuda a ser y a mantenernos en la libertad de amor.

Con la posición agustiniana de Dios Areador, eterno actuante, cuya acción infinita se extiende a la "comprensión incomprensible de todas las cosas incomprensibles" ${ }^{65}$, echa por tierra las bases del retorno eterno. "El munido es temporal, y su comienzo en la existencia no modifica ni e') ser ni la voluntad de Dios. Dios siempre existió en una eternidad inmutable; todo lo demás ha sido hecho" 66. Así entronca San Agustín la eternidad de Dios con el comienzo de la temporalidad en las dos ciudades. Con ellas aparecen en la existencia los seres libires en la llanura del mundo, que realizarán un idestino propio dentro de su uniidad personal de responsabilidad. Con estas criaturas, racionales y libres, entra el mal en el mundo; y la historia es la explicación de los dos bandos contrarios, en constante oposición, llenando la tienra de dolow, sangre y lágrimas; pero, por otra parte, se levanta la misericordia de Dios, abajándose hasta la inmensa miseria del hombre, tománidolo, asumiéndolo, salvándolo, y dando sentido pleno a todo lo humano. Luego nada tienen que hacer los astros en el destino de los hombres, porque es el hombre mismo el inesponsable y el dueño de todas sus acciones; y, por lo mismo, de su destino en el mundo y de la propia histori,a de la humanildad. Luego, también el 'proceso del tiempo no podrá ser detectado en conexiones astrológicas, sino dentro de la teología y de la moral. Adán dejó su huella al pasar por el mundo, construyendo su propia historia, e ini-

65 De civit. Dei XII, 18, PL. 41, 367-368.

66 Ibid. XII, 15, PL. 41, 363-365. 
ciando la de la humanidad entera, y la de cada hombre singular, imprimiéndole una marca indeleble de urebeldía en la ciudad terrena, y señalando también a Dios en el lugar de la Redención y salvación del hombre caído.

Una doble causalidad interviene en el proceso del paso humano por el munido, que es la historia: Dios y el hombre. Esta es la aportación cristiana que Agustín revela a la filosofía y a la teología, en su doble concepción del amor; un amor libre, abierto, desinteresado que creó el mundo en una magna explicatio, aberturna de la bondad divina, acortando las distancias entre lo infinito die Dios y lo limitado del hombre. Casi al mismo tiempo otro amor libre, el de las criaturas racionales -ángeles y hombres-, para unirse a ese amor de Dios ly formar cerrada unidad de caridad, brotó de las entrañas idel Creador. Y en el amor sí que hay un perpetuo movimiento: Dios que se abaja y el hombre que asciende, por asumpción. Así, el retorno eterno del universo en su mecánica ha sido sustituído por la realidad del espíritu, en donde el amor prima y todo lo conmueve: Dios crea por amor, redime por amor y glorifica por amor; el hombre nace por amor, por amor vive ly por amor se une a Dios; sin el amor, que todo la creó, no hay salida posible ni al mundo ni al espíritu. Sin el amor de Dios no se comprenderría el mundo, porque "un Dios que no amara permanecería eternamente recluso en el círculo de su egoísmo, o el universo sería un momento de su proceso evolutivo natural, y por tanto, esencialmente idéntico a él" ${ }^{67}$.

Por dar una salida al amor, Dios se viene al mundo, toma carne de hombrre y redime a la humanidad, rescatándola del pecado y de la muerte: una segunda epifanía de Dios que se inserta en el tiempo para dar y recoger amor, para reparar una culpa ante el Ofendido, y recoger una correspondencia amorosa a esa epifanía divina y mesiánica. San Agustín la llama mediación de Cristo, y que expone en los libros IX, X y XI de La Ciudad de Dios ${ }^{68}$.

El Mediador, por' serlo, se coloca en el centro de la historia. Este Cristo-Mediador, que se hizo mortalmente mortal, se encaró con la muerte misma y con la miseria extrema de los hombres. Todas las teogonías, las cosmogonías, las antropologías y las fillosofías antiguas se enfrentaron

67 V. Capanaga, Los ciclos cósmices en "La Ciudad de Dios"; estudios sobre "La Ciudad de Dios", II, 167 (1956) 106. El Escorial.

68 Quaerendum est melius qui non solum homo verum etiam Deus sit, ut homine ex mortali miseria ad beatam inmortalitatem huius medii beata mortalitas interveniendo perducat (De civit. Dei IX, 15, PL. 41, 268). 
con este tema, profundamente humano, de dar al mundo una mediaciónsalvación: arrancar al hombre ide en medio de sus desgracias; y no pudieron lograrlo, porque traillando al hombre mismo con una pesadísima cadena de desgracias, lo colocaron en la impotencia de romperlas, y no sólo al hombre, sino también a sus dioses. Si previó un modo de rompimiento en estos círculos de las almas -metempsicosis-, como un valor eterno redentor, los eslabones de la miseria le opacaron el oído y le embotaron el sentimiento, apagando la luz que brilló en la revelación de una primera promesa redentora en el paraíso a Adán y Eva. Y así, rodando siglos y siglos, cargando con ella constantemente, a la vista de sus desventuras, inventó la filosofía pagana un consuelo ficticio en el retorno eterno del acontecer y de las almas, para que éstas tuvieran ocasión de redimirse por sí mismas, dando vueltas en redondo y corrigiendo conductas anteriores amorales. Este fue el terrible drama del hombre en las ideologías antiguas. El siempre soñó con la liberación y el rompimiento de sus cadenas; pero, ni la metempsicosis, forma la más paliada de los circuitus animarum, fue capaz de dar al hombre la salvación deseada.

Cristo es para el mundo salvación eficaz, el que rompió las cadenas de nuestra esclavitud. Si el pecado origina en nosotros un movimiento circular de error y de visión a impulsos de los deseos vanos, esto es como la illusión idel que quiere viajar en una plataforma. Estará en constante movimiento, en la inquietud de su desear y saber; pero este estarse en movimiento, siempre en el mismo sitio, es una visión sin lejanías, la situación del impío ${ }^{69}$. El pecado alteró el sentido del tiempo, introcuciendo al hombre en el círculo vicioso de cadenas malsanas. El instante del inocente no es el mismo al del hombre en desgracia. El condenado ve pasar las horas tardas y largas; la senenidad hace al inocente un paso rápido port el mundo y el tiempo. El pecado y la pena por el pecado dan al tiempo una nueva dimensión en la duración-sucesión, que, aunque para el encarcelado y para el libre sean de la misma intensidad real, en el sentimiento y en la apreciación subjetiva varían en la apreciación. No cs lo mismo una noche de fiesta y alegría que una noche de agonía y dolor. El pecado fue quien sumergió al hombre en la profundidad del tiempo y en el movimiento circular de sus miserias.

Ante la impotencia humana de escapar a esta servidumbre y de

69 Ps. 11, 9. 
alcanzar el descanso en su inquieto andar, viene la necesidad de una mediación, que trajo efectiva Cristo al mundo para la humanidad entera. También los paganos han buscado esta mediación para el hombre. Porfirio y Apuleyo se apoyaron en los demonios-demiurgos para una purificación de las almas, intentanido así arrancarlas de esta dimensión de miseria y existencia angustiante, parla colocarlas en un lugar de reposo. Ignoraron a Cristo-Mediador; no se dieron cuenta de que El es el Redentor de los hombres, porque es sumo sacerdote, oferente y victima, sacrificio de nuestra expiación ${ }^{70}$. Con su sacrificio Jesucristo realizó el acto de conciliación y mediación más excelente; pues $\mathrm{El}$ restableció la amistad entre el cielo y la tiertra ${ }^{71}$.

A San Agustín no le importa casi la vida del cuenpo, porque éste se asienta en un lugar circunstante y en un tiempo determinado; le vale más la vida del espíritu, a quien no le interesa el tiempo ni el espacio. Teniendo y asiéndose a una realidad superior, el hombre se asienta en lo inmortal. El lugar no interesa, porque sería encerrrar a la humanidad entristecida en un cerco apretado y sin salida a la transcendencia. Tampoco el tiempo, porque es algo que pasa; y el espíritu anhela lo que permanece, y pretende situarse sobre el instante. Tiempo y espacio cuentan muy poco en La Ciudad de Dios, porque ésta se alarga a través de las edades, sobrepasánidolas, y se extiende más allá del lugar, transcendiéndolo, para colocarse en la cima de todo. La Ciudad de Dios es intemporal y aespacial, y su centro es Cristo-Redenición, por el que los hombres, que se salvan, no retornarán a otra existencia miserable, sino que brillarán como las estrellas en el cielo etterno, ni los que se condenan volverán a tomar otro cuerpo para buscarse una purificación ya imposiEle. Por eso, por ser intemporal la Ciudad de Dios, ocupa su centro el Cristo-Mediador. La historia se dividirá, por lo mismo, en tres partes: antes de la venida de Cristo, realidad humana de Cristo en la tierra y tiempo de redención de después de la venida idel Salvador; o si se quiere, solamente en dos: anteriora Christi y en 'posteriora Christi.

Con su llegada Cristo llama a todos los hombres a la vida eterna, a la participación de su divinidad ${ }^{72}$. Esta participación de vida eterna,

70 Per hoc et sacerdos est, ipse offerens, ipse et oblatio (De civit. Dei X, 20, PL. 41, 298).

71 Cristo murió una sola vez por nuestros pecados; resucitando de la muerte, ya no muere, ya no le dominará otra vez la muerte; y nosotros, después de la resurrección, estaremos siempre con $\mathrm{El}$ en el Señor (De civit. Dei XII, 13, PI. 41, 362)

$7_{2}$...ut per haec efficiamini divinae consortes naturae (I Petr. 1, 4). 
iniciada con la vida en gracia, significa el descanso y punto de reposo a la constante inquietud humana ${ }^{78}$. "Todo hombre busca reposo; buena cosa busca, aunque mo en la región en donde se encuentra. No está la paz en la vida presente; en el cielo se halla lo que aquí se nos ha prometido, lo que buscamos en la tierra" "74. Esta paz y descanso no sólo es para el alma; también el cuerpo reclama sosiego en el caminar inicesante. Está también hecho para formar' y conformar la persona humana juntamente con el espíritu; y los dos se reclaman esencialmente en una atracción imperiosa y natural ${ }^{75}$. Toda la antigüedad vislumbró esta necesidad humana, y la explicó a su modo con sus transmigraciones del alma a cuerpos diversos, y con esos circuitos, o retorno eterno. Este reencuentro del alma con el cuerrpo, preanunciado en la resurrección del SalvadorMediador, no se dará más que una sola vez, y no se repetirá nunca ${ }^{76}$. Luego del encuentro no habrá más que paz y serenidad en un orden de unidad inmutable en los ciudadanos de la civitas Dei. Porque, desterrándose ya el pecado, con él desaparece el cansancio. "En aquella ciudad la voluntad libre será ya enl todos e inseparablemente en cada uno, libre de todo mal y llena de todo bien, diisfrutando indefectiblemente de la suavidad de los goces eternos, olvidada de las culpas, olvidada de las penas, pero sin olvildarse de su liberación, para no ser ingrata a su libertad" "77. Y seguirá un sábado eterno, "que no tendrá tarde, y será como el domingo eterno del Señor, que prefigura no sólo el descanso del cuerpo, sino también el del alma. Allí descansaremos y contemplartemos, contemplaremos y amaremos, amaremos y alabaremos; he aquí lo que será el fin aue nor tieme fin" 78 .

Cristo, siendo el apicentro de la historia, es también la solución de todas las dificultades, la refutación de todos los errores paganos y de sus círculos y ciclos arbitrarios. Cristo es el centro y empuje de la Ciwdad de Dios, y del corrazón de Agustín, que entraña una significación de toda la humanidad, peregrina de todas las rutas.

\footnotetext{
73 Conf. I, 1, 1, PL. 32, 661.

74 Enn. in ps. 48, 2, 6, PL. 36, 560

75 Quanto honestius creditur, reverti semel animas ad corpora propria, quem reverti toties ad diversa? (De civit. Dei X, 30, PL. 41, 310). $370)$.

76 Nullo repetita, nullo repetenda circuitu (De civit. Dei XII, 20, PL. 41,

77 Ibid. XXII, 30, PL. 41, 704-708.

78 Ibid.
} 


\section{C.- -Tiempo agustiniano.}

El problema del tiempo en San Agustín entraña otros muchos prohlemas: el bien y el mal, la entrada idel hombre en el mundo, la explicación del ser del hombre...; y ide entre los divinos, el principal, el de la Encarnación, y la historia de la salvación del hombre, la intervención de la eternidad en el tiempo... Todo esto no lo puldieron imaginar y menos entender los griegos, que, envueltos dentro de un evolucionar del rotundo eterno, nada sabían y nada pudieron sabier ide la bajada de Dios a esta llanura temporal sin pender nada de su esencia divina. Nada supieron tampoco del sentido de la historia, del principio del mal en el tiempo - comprensible en medio de dos principios antagónicamente contrarios y eternos en los maniqueos y algunas escuelas paganas-, nada de la conversion-inicio del hombre nuevo, de la libertad y responsabilidad personalles, del arrepentimiento, de la escatología...' Nada ide esto supo nadie fuera del Cristianismo, porque nada de esto es comprensible sin una realidad de iluminación por la revelación, y sin una realidad de la sucesión; y esto para San Agustín, identro de su Cristianismo, era experiencia personal, $y$, por lo mismo, una intuición y una vivencia, que le regaló el Catolicismo, vivo en la Iglesia.

Agustín se encara con sinceridad con la pregunta sabre el tiempo, porque en todo ve un moverse constante, que amenaza su aspiración a lo eterno ${ }^{79}$. El quiere comprender y compreniderse-comprometerse en la eternidad, siempre estable, sin el engorro de los instantes móviles ${ }^{80}$. Por eso mismo, el movimiento no es el movimiento del sol, o de las estrellas, no es el día ni la noche ${ }^{81}$. El inicio del tiempo ttiene comienzo en la Palabra-Verbum-del Padre, que es el principio en quien y por quien fueron hechas todas las icosas ${ }^{82}$. Como esa Palabra se despliega hacia fuera

79 Conf. XI, 11, 13, PL. 32, 814.

80 Quis tenebit illud et figet illud, ut paululum stet et paululum rapiat snlendorem semper standis aeternitatis et comparet cum temporibus nunauam. stantibus, et videat esse incomparabilem; et videat longus tempus nisi ex multis rraetereuntibus motibus, quae simul extendit non possunt, longum non fieri, non autemn praeterire auicquam in aeterno, sed totum esse praesens; et videat omne praeteritum propelli ex futuro, et omne futurum ex praeterito consequi et omne nraeteritum ac futurum $a b$ eo, quod semper est praesens, creari et excurrere? Quis tenebit cor hominis, ut stet et videat, quomodo stans dictet futura et praeterita tempora aeternitatis? Nunauid manus men valet ant manus oris mei per loquellas tam grandem rem? (Conf. XI, 11, 13, PI. 32, 814).

81 Ibid. XI, 23, 29, PL. 32, 820.

82 Jn. $1,3$. 
en el tiempo, ahí, en ese mismo instante, comienza también la historia, conjuntamente con ell tiempo; y ahí tiene tambiénl su origen la civitas hominis, como un campo en donde se debaten los poderes ide dos ciudades, la del bien y la del mal. Se habla del tiempo; la etennidad es un presente-inmutable, un hoy permanente. El tiempo es algo que corre, que se va; o un algo que hace que nosotros nos vayamos también; y un algo que medimos en y por el alma. Y si lo medimos allí, los momentos del tiempo son en función de una presencia, de la que el alma es el centro. Y siendo el tiempo una disensión, ¿ino lo será también el alma misma? El tiempo no es movimiento de cuerpos. El hombre y su vida humana son en y por el tiempo, y toda ella una Idistensión, por la que algo pasa. ¿No será esto el tiempo?

"¿Qué es, pues, el tiempo? ¿Quién podrá explican esto fácil y brevemente? ¿Quién podrá comprenderlo con el pensamiento, para hablar luego de él? Y, sin embargo, ¿qué cosa más famıliar y conocida mentamos en nuestras conversaciones que el tiempo? Y cuando hablamos de él, sabemos sin duda qué es, como sabemos y entendemos lo que es cuando lo oímos pronunciar a otro. ¿Qué es, pues, el tiempo? Si nadie me lo pregunta, lo sé; pero si quiero expresárselo al que me lo pregunta, no lo sé. Lo que sí digo sin vacilación es que sé que si nada pasase no habría tiempo pasado; y si nada sucediese, no habría tiempo futuro; y si nada existiese, no habría tiempo presente. Pero aqueIlos dos tiempos, pretérito y futuro, jcómo pueden ser, si el pretérito ya no es y el futuro todavía no es? $\mathrm{Y}$ en cuanto al presente, si fuese siempre presente y no pasase a ser pretérito, ya no sería tiempo, sino eternidad. Si, pues, el presente para ser tiempo es necesario que pase a ser pretérito, juómo decimos que existe éste, cuya causa o razón de ser está en dejar de ser, de tal modo que no podamos decir con verdad que existe el tiempo en cuanto tiende a no ser?" ${ }^{83}$.

No hay lugar a duda que el tiempo es un suceder, una sucesión. Pero, ¿sucesirón de qué? ¿Del munido, de las cosas, del alma? Es un llegar a ser, y un llegar a no ser lo que antes se era. El tiempo -el hoyes un algo, que, radicándose como sujeto en el presente-instante, del pasado no posee nada y que del fruto nada tiene a su alcance. El tiempo pudiera definirse como un paso de un modo de ser a otro modo de ser, del modo de ser del instante-ahora por el que ha-sido devendrá en un 
haber-de-ser-siendo. "¿Quién no ve que el tiempo no puede existir todo él presente, sino que todo pretérito es empujado por el futuro, y que todo futuro es precedido de un pretérito, y que todo preténito y futuro es creado y transcurre porr lo que es siempre presente?" ${ }^{84}$. Luego, toda actualidad' de presente no puede entenderse más que por una referencia intencional a la eternidad: la conciencia - presente- sería como una correspondencia de presencia ontológica, por la que el tiempo es tiempo, $\mathrm{y}$ es posible de medirlo la conciencia.

El tiempo, siendo caducidad, es muerte constante, y tiene su existencia y sistencia en cuanto el ser-nunc tiende a desaparecer para llegar el ser-siendo a no-ser. "Y, sin embargo, decimos "tiempo largo" y "tiempo breve", lo cual no podemos decirlo más que del tiempo pasado y futuro. Llamamos tiempo pasado largo, v. gr., a cien años antes de ahora, y de igual modo tiempo futuro largo à cien años después; tiempo pretérito breve, si decimos, por ejemplo, hace diez días, y tiempo futuro breve, si identro de diez días. Pero, ¿cómo puede ser largo o breve lo que no es? Porque el pretérito ya no es, y el futuro todavía no es. No digamos, pues, "es largo", sino, hablando del pretérito, digamos que "fue largo", y del futuro, que "será largo".

" OOh Dios mío y luz mía!, ¿no se burlará en esto tu Verdad del hombre? porque el tiempo pasado que fue largo, fue largo cuando era pasado ya o tal vez cuando era aún presente? Porque entonces podría ser largo, cuando había de qué ser largo; y como el pretérito ya no era, tampoco podía ser largo, puesto que de ningúnı modo existía. Luego no digamos: "El tiempo pasado fue largo", porque no hallaremos qué fue largo, por la razón de que lo que es pretérito, por serlo, no existe; sino digamos: "Largo fue aquel tiempo siendo presente", porque siendo presente fue cuando era largo; todavía, en efecto, no había pasado para dejar de ser, por lo que era y podía ser largo; pero después que pasó, dejó ide ser largo, al punto que dejó de existir" ${ }^{85}$.

Para conocer el pasado, y aún el futuro, tenemos que hacer relación-sucesión al presente. "Veamos, pues, alma mía, si el tiempo presente puede ser largo, se te ha dado sentir y medir los intervalos" ${ }^{86}$. Nada se puede tener por presente, porque nada más pensarlo, ya se escapó de nosotros. Cien años no son presente; uni año tampoco lo es;

84 Conf. XI, 11, 13, PL. 32, 814.

85 Ibid.

86 Ibid. XI, 15, 19, PL. 32, 816-817. 
ni siquiera un día es presente, porque en él hay pasado. El presente es un casi pasado, o un presente-instante y un futuro que se acenca al alma $o$ a la consciencia del momento ${ }^{87}$. "He aquí el tiempo presente -el único que hallamos debió llamarse largo-, que apenas si se reduce al breve espacio de un día. Pero discutamos aún esto mismo. Porque ni aún el día es todo él presente. Compónese éste, en efecto, de veinticuatro horas entre las nocturnas y las diurnas, de las cuales la primera tiene como futuras las restantes, y la últtima como pasadas las demás, y cualquiera de las intermedias tiene delante de ella pretéritas y después de ella futuras. Pero aún la misma hora está compuesta de partículas fugitivas, sienido pasado lo que ha transcurrido de ella, y futuro lo que aún le queda.

"Si, pues, hay algo de tiempo que se pueda concebir camo indivisible en partes, por pequeñísimas que éstas sean, sólo ese momento es el que debe decirse presente; el cual, sin embango, vuela tan rápidamente del futuro al pasado, que ni se detiene un instante tan siquiera. Porque, si se detuviese, podría dividirse en pretérito y futuro; y el presente no tiene espacio ninguno.

“¿Dónde está, pues, el tiempo que llamamos largo? ¿Será acaso el futuro? Ciertamente no podemos decir de éste que es largo, porque todavía no existe qué sea lango; sino decimos que será largo. ¿Cuándo, pues, lo será? Porque si entonces fuere todavía futuro, no será largo, porque todavía no hay qué sea largo; y si fuere largo, cuando saliendo del futuro, que todavía no es, comenzare a ser y fuese hecho presente para poder ser largo, ya clama el tiempo presente con las razones antedichas, que no puede ser largo" ${ }^{88}$. Y así volvemos a empezar, porque nos encontramos como al principio, sin saber nada de lo que es el tiempo. A San Agustín le interesa seguir con el tema del tiempo, porque se ha lanzado a dar una explicación a la profecía, que se anuncia en el presente para realizarse en el futuro-presente, y algunas veces con proyección hacia el pasado.

Estamos en medio de la encrucijada, y sin haber progresado nada en el tema sobre el tiempo. Presente, pasado y futuro no son ni largos ni cortos, porque, llanamente, podemos decir que no son. Sin embargo, de todo hemos sacado una conclusión: sentimos el tiempo. "Sentimos los intervalos de los tiempos y los comparamos entre sí... Tambiénı me-

\footnotetext{
87 Conf., 15, 13, PL. 32, 815-817.

88 Ibid. XI, 15, 20, PL. 32, 817.
} 
dimos ouánto sea más largo o más corto aquel tiempo que éste, y decimos que éste es doble o triple y aquél sencillo, y que éste es tanto como aquel. Ciertamente nosotros medimos los tiempos que pasan cuando, sintiéndolos, los medimos... Porque cuando pasa el tiempo puede medirse; pero cuando ha pasado, ya no se puede, porque no existe" ${ }^{89}$.

También concluímos con San Agustín: el tiempo es algo que pasa, y que, mientras pasa, lo sentimos y medimos en su duración. Luego, es algo real, no pra imaginación, sugestión o apariencia; es algo que sentimos y medimos, algo que tiene ser ontológico, y que, como tal, lo apreciamos en la consciencia. Luego, también la consciencia es la medida de la duración de ese ser, que pasa luego, para volver a aparecer siendo ${ }^{90}$. Por consiguiente, si el tiempo es algo que pasa y que afecta mi sensibilidad, es algo que también dura en su pasar. Tanto, que hay momentos en mi vida que son larquísimos y momentos que se me pasan con rapidez. ¿Qué ocurre en ambos casos? Simplemente, puede ser la monotonía en que me encuentro presente a las cosas, y que me causan enfado, y entonces expreso este enfado a mi conciencia con el disgusto de tenerlas a la mano; pero, cuando las cosas, a las que me hago presente, me agradan, el momento en que estoy con ellas se me hace corto. También puede suceder que para unos el mismo instante presente sea corto y largo para otros. Y todo porque la sensibilidad obra en sentido de duración, vibrando al unísono del estado de ánimo placentero o adverso; triste o alegre, distraído o atento. Dos actitudes distintas se pueden captar en el suceder de los instantes.

Sólo hay un tiempo presente - dice San Agustín - . Pero además existen cosas y hechos que se realizaron en el pasado -historia-, y cosas y hechos que sucederán. "Pregunto, yo, Padre, no afirmo; 1 Oh Dios mío!, presídeme y gobiérname. ¿Quién hay que me diga que no son tres los tiempos, como aprendimos de niños y enseñamos a los niños: pretérito, presente y futuro, sino solamente presente, por no existir aquellos dos? ¿Acaso también existen éstos pero como procediendo de un sitio oculto cuando de futuro se hace presente, o retirándose a un lugar oculto cuando de presente se hace pretérito? Porque si aún no son, ¿dónde los vieron los que predijetion cosas futuras?; porque en modo allguno puede ser visto lo que no es. Y los que narran cosas pasadas no narran cosas verdaderas, ciertamente, si no viesen

89 Conf. XI, 16, 21, PL. 32, 817.

90 In te, anime meus, tempora mentior (Conf. XI, 27, 36, PI. 823). 
aquéllas con el alma, las cuales, si fuesen nada, no podrían ser vistas de ningún modo. Luego existen cosas futuras y pretéritas" ${ }^{91}$.

Luego, el pasado y el futuro, también el presente, son connotación al ser; y el ser es siempre en presencia; si no, no sería, no existiría en sistencia. El ser en cuanto ser se refiere siempre a un presente, porque es lo que siempre está ahí, en el lugar, o donde sea; pero que está ahí. Luego, el pasado y el futuro son algo real en cuanto conotan a un presente. "Permíteme ir delante en mi investigación, Señor, esperanza mía; que no se distraiga mi atención. Porque, si son las cosas pretéritas y futuras, quiero saber dónde están. Lo cual si no puedo todavía, sé al menos que, dondequiera que estén, no son allí futuras ni pretéritas, sino presentes; porque si son allí futuras, todavía no son, y si son pretéritas, ya no están allí; dondequiera, pues, que estén, qualesquiera que ellas sean, no son sino presentes. Cierto que cuando se refieren a cosas pasadas verdaderas, no son las cosas mismas que han pasado las que se sacan de la memoria, sino las palabras engendradas por sus imágenes, que pasando por los sentidos imprimieron en el alma huella. Así, mi puericia, que ya no existe, existe en el tiempo pretérito, que tampoco existe; pero cuando yo recuerdo o describo su imagen, en tiempo presente la intuyo, porque existe todavía en mi memoria. Ahora, si es semejante la causa de predecir los futuros, de modo que se presientan las imágenes ya existentes de las cosas que aún no son, confieso, Dios mío, que no lo sé. Lo que sí sé ciertamente es que nosotros premeditamos muchas veces nuestras futuras acciones, esta premeditación es presente, no obstante que la acción que premeditamos aún no existe, porque es futura; la cual, cuando acometamos o comencemos a poner por obra nuestra premeditación, comenzará entonces a existir, porque entonces no será futura, sino presente.

"Así, pues, de cualquier modo que se halle este arcano presentimiento de los futuros, lo ciento es que no se puede ver sino lo que es. Más lo que es ya, no es futuro, sino presente. Luego, cuando se dice que se ven las cosas futuras, no se ven estas mismas, que todavía no son, esto es, las cosas que son futuras, sino a lo más sus causas o signos que existen ya, y, por consiguiente ya no son futuras, sino presentes a los que las ven, y por medio de ellos, concebidos en el alma, son pre-

91 Ibid. XI, 17, 22, PL. 32, 817-818. 
dichos los futuros. Los cuales conceptos existen ya a su vez, y los intuyen presentes en sí quienes predicen aquéllos.

"Explíqueme esto un ejemplo tomado de la misma multitud de cosas. Contemplo da aurora, anuncio que ha de salir el sol. Lo que veo es presente; lo que predigo, futuro: no futuro el sol, que ya existe, sino su orto, que todavía mo ha sido. Sin embargo, aún su mismo orto, si no lo imaginara en el alma como ahora cuando digo esto, no podría predecirlo. Pero ni aquella aurora, que veo en el cielo, es el orto del sol, aunque le preceda; ni tampoco aquella imaginación mía que retengo en el alma; las cuales dos cosas se ven presentes, para que se pueda predecir el futuro. Luego no existen aún como futuras; y si no existen aún, no existen realmente; y si no existen realmente, no pueden ser vistas de ningún modo, sino solamente pueden ser predichas por medio de las presentes que existen ya y se ven" ${ }^{92}$. La conclusión de Agustín es magnífica. "Lo que ahora es claro y manifiesto es que no existen los pretéritos ni los futuros, ni se puede decir con propiedad que son tres los tiempos: pretérito, presente y futuro; sino que tal vez sería más propio decir que los tiempos son tres: presente de las cosas pasadas, presente de las cosas presentes y presente de las cosas futuras. Porque éstas son tres cosas que existen de algún moido en el alma, y fuera de ella yo no veo que existan: presente de las cosas pasadas (la memoria), presente de las cosas presentes (visión) y presente de las cosas futuras (expectación).

"Si me es permitido hablar así, veo ya los tres tiempos y confieso que los tres existen. Puede decirse también que son tres los tiempos: pasado, presente y futuro, como abusivamente dice la costumbre; dígase así, que yo no curo de ello, ni me opongo, ni lo repudio; con tal que se entienda lo que se dice, y no se tome por ya existente lo que está por venir ni lo que es ya pasado. Porque son pocas las cosas que hablamos con propiedad, muchas las que decimos de moido impropio, pero que se sabe lo que queremos decir con ellas" ${ }^{93}$.

De lo que sí podemos hablar es de un recuerdo de algo que con nosotros estuvo en presencia real, y que ahora lo está en nuestra meinoria, de un momento actual que la atención y la intuición ven y captan, y de algo que estará con nosotros como visión, y que ahora existe en nuestra conciencia como expectación. Tres dimensiones humanas

92 Ibid. XI, 18, 23-24, PL. 32, 818-819.

93 Ibid. XI, 20, 26, PL. 32, 819. 
abarcando tres modos del tiempo y según las distintas facultades del alma. El tiempo existe en sí, como algo ontológico, porque si no existiera, en modo alguno se haría presente en la intimidad humana.

Es cierto que para San Agustín el tiempo queda encuadrado en el alma. Luego, el tiempo es una cierta distensión del alma. Esta distensión, que incluye o se extiende por todas y cada una de las facultades humanas, hace que el alma quede como prendida del tiempo. A esta distensión podíamos calificarla como de temporalidad, y abarcando las tres proyecciones del tiempo: pasado, presente y futuro. Si al hablar del hombre podemos decir de él que es el ser que se actualiza en cada momento, al alma la podemos definir como un temporalizanse, porque su sistencia se realiza en su existir, que es temporalidad. Así, el hombre, al realizarse, constituyéndose, va haciendo también su propia historia, cristalizando en actos ese su quehacer constante del momento. El hombre es temporalidad, ponque, al radicarse en sí, se remonta definiendo su ser. En el primer instante de su aparición en la vida es ya un arranque de acción con el que va a devenir a lo largo de su existencia. En este sentido la vida es tiempo, con tres modos de temporalidad, o tres dimensiones vitales, que encarnan el ser total del hombre, o tres partes de una misma historia, en las que el hombre está integrándolas, siendo solamente uno y único. Y esto es lo genial en San Agustín : esta visión de totalidad de la vida del hombre, como una gran integralidad, que se va alargando desde su comienzo en la existencia hasta su meta final en la misma muerte. Pero no sólo esto; hay más. Lo que dice de un hombre concreto, del propio Agustín histórico, lo aplica a la humanidad entera, y en especial a la historia de la humanidad. Así, con San Agustín sólo podemos hablar de una historia, de una civilización y de una cultura; de la de toda la humanidad.

Medir el tiempo es poder estar sobre el tiempo, y aún condicionarlo. Lo que hace el alma al penetrarlo es decir que es mudable; y en su aspecto de mutabilidad lo está juzgando. Pero téngase en cuenta que este juicio no puede hacerse desde la posición del presente, porque también éste es muldable, esencialmente mudable, y que no ofrece apoyo alguno seguro. Luego, el alma tiene que buscarse otro punto de apoyo en una estabilidad de fuera del tiempo, en la eternidad; porque para comprender y medir el tiempo es necesario trascenderlo. Este contacto del alma con la eternidad es lo que le da a ella firmeza y estabilidad, es lo que la hace a ella, incluso, intemporal-inmortal. El alma está 
siempre en contacto con el bien y la verdad, que son eternos; lo mismo con los números, que presiden el juicio ${ }^{94}$.

Aún el tiempo en su dimensión de presente es una connotación a la eternidad, presente inmutable. Así, el tiempo de la misma ${ }^{95}$. Pero el tiempo no es nombre de eternidad; es sí camino hacia ella, duración real que el alma percibe. El tiempo tiene su medida ontológica en la eternidad ${ }^{96}$.

El tiempo medido por el alma es el tiempo psicológico, pero que nos enfrenta al ontológico, o tiempo en sí. El alma, al medir comprendiendo la fugacidad del tiempo, se lanza con ímpetu inquieto a la búsqueda y alcance del momento quieto, hacia donde haya perduración sin mutabilidad, a lo permanente; es su ansia insatisfecha la que la empuja a la permanencia ${ }^{97}$.

Hay un tiempo psicológico -mi hora, yo en mí-, un tiempo histórico - yo hice, los demás hicieron, hago, haré- y un tiempo absoluto - instante - camino de la eternidad. De todos ellos el que más interesa, personalmente, es el psicológico, el que naciendo con la libertad del hombre, va siempre con el individuo. Pero el tiempo, si puede pesar sobre el hombre, no puede engendrarlo; es el hombre el que se coloca sobre el tiempo-instante, porque cada hombre en cierto modo, engendra su tiempo. Luego, si yo no estory en el tiempo, es él el que está en mí, y de mí depende, porque sory yo quien lo engendra, y el que lo gasta en bien o en mal. Es por esto por lo que el hombre no pertenece a un tiempo, que comienza con cada individuo. Pero también es cierto que cada hombre recibe de Dios su tiempo en el momento en que es hecho persona, en el de la consciencia y vida, el del intervalo

94 M. Iudiciales illi numeri vinculo temporis in tanto spatio tenoretur, quanto isti sonantes digesti sunt; possentne ad eorum sonantium, qui paulo productius eadem iambica lege funduntur, aspirare iudicium?

D. Nullo modo.

M. Igitur apparet hos mora temporum, aut iudicando praesident, non teneri.

D. Prorsus apparet (De musica VI, 17, PL. 32, 1.191).

95 Haec enim nunc dixi tempora qui intervallorum distinctione aeternitatem inconmutabilem supra se manere significant, ut signum, id est, quasi vestigium aternitatis tempus apparet (De gen. ad litt. imper lib. 13, 38, PL. 34, 236). (Cfr. De musica VI, 11, 29, PL. 32, 1.179).

96 Dies nostri per hodiernum tuum transiemunt et ex nihilo acceperunt modos (Conf. I, 6, 10, PL. 32, 665).

97 Stabo atque solidabor in te, in forma mea..., veritate tua (Conf. XI, 30, 40, PL. 32, 825). Ecce distensio est vita mea..., et a veteribus diebus colligar sequens unum, "praeterita eblitus", non in ea quae futura et transitura sunt, sed, "secundum intentionem sequor ad palman vecationis..." (Conf. XI, 29, 39, PL. 32, 825). 
nacer-morir. Si el tiempo es una distensio animi ${ }^{98}$, viene a ser algo así como un espacio interior, engendrado por la voluntad libre en el instante-presente, que se alarga hacia un pretérito y se dirige hacia un porvenir $^{99}$.

Con toda propiedad, pues, se puede decir que el tiempo es el movimiento de la voluntad con el que el hombre se hace o constituye. Luego, hay un tiempo psicológico, dentro del cual cae el plano externo del acontecer', y hay también otro plano de interioridad en el que se hace mi vida intencionalmente hacia las cosas; y los dos son mi tiempo, que se cristializa en el instante-prapesens. Con los dos momentos me lanzo en la existencia y realizo mi persona, o me desvío de mi vocacióndestino, despersonalizándome en la diáspora. Más aún. Para entenderse pienso en mi tiempo-inicio, el que no es ni para esto ni para aquello, pero que será para alguno de ellos. En él me alimento y me lleno de deseos: momento de pensar en mi vocación total, o de mi vocación a algo particular, que me acumulará en mi vocación total. $\mathrm{Y}$ como el deseo es ansia de plenitud, mi tiempo inicial me empuja, o yo lo empujo a él, a la realización de mi ser-persona. El tiempo-inicio es ansia de ser y de consmensuración con el ser a plenitud. Al tiempo-inicio le sucede el tiempo-realidad-vida, en el que me voy haciendo por la respuesta a mi vocación y puesta in re del deseo. Es momento de actuaciones, campo de bien y de mal, de santificación y de pecado, tiempo de bistoria. La voluntad se distiende en realización de valores, coordinación entre las necesidades de la vida y las exigencias de la existencia. Tiempo-duración en la existencia, que es el plantificarse el hombre en todo lo humano y sobre lo inhumano; tiempo también de historia.

Siendo también el hombre tiempo, es tiempo-inicio, tiempo-vida y tiempo-permanencia en la existencia. Por lo que el hombre, si tuvo principio, no tendrá fin, absolutamente hablando, porque es inmortal; si el tiempo se acaba, el hombre permanecerá siempre en su existencia. Su cometido, como su vocación, es a perpetuidad; su existir no acaba en y con la muerte; la traspasa para implantarse en perpetuidad duradera. La eternidad lo envolverá, y será siempre. Es inmortal en su alma, aunque su cuerpo permanezca sin vida algunos momentos del tiempo. Así, el tiempo humano, como el hombre, nunca se agota; una vez comenzado el tiempo-inicio, ni se anula, sino que cada vez se perfec-

98 Conf. XI, 23, 30; 26, 33, PL. 32, 820-821; 822.

99 In te, anime meus, tempora mentior. (Conf. XI, 27, 36, PI. 32, 823). 
ciona más, porque la eternildad lo cubrirá para siempre, y totalmente. La historia terminará -es lo único que termina en el hombre-; pero la existencia-tiempo y el tiempo-existencia seguirán unidos a cada hombre, ya inmortal. Siendo el tiempo también un constitutivo ontológico para el hombre, ninguno ide los idos - ni hombre ni tiempo- pueden acabarse, sino más bien perfeccionarse, llegar a la plenitud y llenarse de perfección. Desde el momento en que el hombre aparece en la vida, camina ya en existencia perpetua: todo lo suyo se llena de tiempo; o mejor, el tiempo suyo se llena de su existir, y los dos constituyen temporalidad, que ya no se apagará, sino que se convertirá en lo perpetuo, en lo sin fin en la duración. Siempre existirá para el hombre su es-hoy, y una mirada al fwe-ayer, y una perspectiva hacia su será-mañana, y todo en momento de presencia perpetua en la permanencia de su consistencia. Y porque el hombre fue implantado en su sistencia por DiosCreador, es por lo que él caminará siempre en su tiempo-hora. Por lo mismo se nos ocurne pensar que el hombre, si hace historia, no es histórico, porque no pasa al pretérito, sino que queda injertado en su presente-siempre-ahora. Lo que se inserta en el pasado no es el hombrepersona, es el hombre-actuar, sus acciones, que son las que se queidan siempre atrás. El hombre siempre marcha, va hacia, nunca retrocede; ni aún cuando peca retrocede, sino que se aparta, declina del recto camino. La historia-tiempo acaba con la muerte ide cada uno; pero aún le queda al hombre el tiempo-existencia, con el que sigue siendo más allá de la muerte.

El tiempo de cada hombre no se confunde con la historia del mundo, ni aún con la propia historia de cada hombre-persona, porque lo que se acaba del hombre es una forma externa, que ésa sí termina por un tiempo, para cumplir su destino-castigo por el pecado. Lo inmortal no puede acabar, sigue siendo en el ahora-siempre penpetuo. Esto es tan crerto, que el tiempo de vidarcuerpo rescatado con la resurrección, coincidiendo con aquel ahora la inmortalidad con la integridad perfecta del individuo. Es la victoria del tiempo-gracia sobre el tiempo-pecado: es la elevación del tiempo-existencia al tiempo-inicio de la humanidad adámica en el escogimiento absoluto, en donde do intemporal-eterno de Dios es medida de la medida humana-tiempo. Es ya entonces el EternoPresente, que se extiende - por hablar en humano- sobre el tiempo del hombre, que comienza a ser presente eterno en su bienaventuranza: una distensio animi en el Reino de Dios, como expresión plástica de la 
socialización total en Cristo, o tiempo definitivo del Cuerpo Místico, inicio de la plenitud del Reino de Dios.

La distensio animi es ser en el presente, que implica conservar la libertad en onden intencional de rectitud, en una constante atención, o cura de sí mismo ${ }^{100}$. La vigilancia se hace siempre en presente, y es toque de atención al grito de la carne insinuante, y situación de escucha a la voz de la vida, que llama al onden en el escoger y practicar el bien. Esta atención exige esfuerzo en el presente-actuación, que, siendo contuitus, es a la vez creencia - expectatio - y memoria - recuerdo de pasado-. La attentio-contuitus se mantiene en despliegue; por eso, el hombre, instalado en su presente-instante, es perspectiva y retrospección. En el presente-ahora se le dan el presente-pasado y el futuro-presente. Tres situaciones aparentemente aisladas, pero unidas en un solo momento: retrospección-visión-creencia, que recoge la totalidad de la existencia en cualquier punto humano. Todo dentro de la magna actividad libre dentro de la consciencia de cada hombre. La consciencia es lo que une todo -pasado, presente y futuro- dentro de una sola manifestación unacional de la cogitatio. El presente-distensio-animi es siempre consciencia-cogitatio-reflexión, o un darse cuenta de que siempre-ahora se es el mismo en cada instante: es la síntesis humana de los momentos-tiempo. La consciencia asume sobre sí el peso-responsabilidad de la historia singular en colaboración con la obra común de la historia de la humanidad. Así, la consciencia hace posibile la perennidad del hombre en cada instante, y lo que le hace que no quede uoto fragmentariamente entre los sucesivos momentos del tiempo, sino que converja todo en la unidad del presente-ahora.

La voluntad, como contenido de libertad, es aceptación de todo lo nuestro y de lo que nos viene como del fondo del ser indiferente, por cualquier interés vital. El movimiento de la voluntad en elección es siempre impulso del amor -eligere idem est ac diligere- No es nunca la voluntad, bien ordenada, un deseo de posesión, sino amor de servicio hacia una persona, o hacia un ser cualquiera. Cuando la voluntad es deseo de posesión y uso, se convierte en cupididad-cupiditas, en concupiscencia, en sensualidad. La entrega al ser debe estar informada por el desinterés; nunca por lo que nos sirve, ni por lo que nos vale, sino por donación del uno al otro, amorosa y amantemente. Cuando esto

100 La cura heideggeriana tiene este mismo significado. 
sucede, el ser-bien-verdad no es tomado en posesión, sino escogido, elegido como bien que es mi bien, y que se me pone en el plano de mi existencia. Así todo ser pertenece al plano del interés vital, y es elevado, al asumirlo la voluntad, al otro a través del servicio de mi voluntad, en donde y solamente se le registra y descubre en su verdad de ser, y se le profundiza en su significado de ente: ahí se le conoce como tal, y en él se descubre todo el misterio de su entidad-realidad.

La elección es liberante de la propia libertad y de lo demás que entre en ella, porque el ser es límite, no finalidad-motivo de la voluntad; y cuando voy al ser, es porque en él y por él me hago más yo, me constituyo más en mí mismo; es porque lo necesito para mi perfección, y porque él me libera de otras elecciones. Cuando lo he tomado, dejo de caminar, ya no estoy en tránsito, sino en parada; porque todo ser, por el ser que es, es perfección, y es para mí alegre estancia en el amar, según la graduación jerárquica de valores. Ningún ser creado, sin embargo, me ofrece parada definitiva, sino sólo un descanso en el camino y una señal hacia Dios. Todos los seres están en la posibilidad de mi clección; y cuando escojo uno, los demás siguen siendo entes para escoger y todavía no elegidos. Lo mismo en las acciones; de entre muchas me inclino por una; las demás quedan en la posibilidad de mi escogimiento. Esta es la libertad humana frente a la acción, frente al ser y frente a los valores del ser. Ahora lo que importa en la elección, en el escogimiento, es una iluminación, que en toda elección existe, cuando la elección recae en un ser en razón de su verdad ontológica y de su bondad axiológica. Cuando no, es que una imponente oscuridad ha caído sobre la facultad humana - voluntad- por una tergiversación del intelecto. Siempre que las dos facultades humanas marchan tras lo bueno y lo existente ontológico y de su bondad axiológica en la rectitud del ser, se escoge lo bueno y se obra en bondad. El uti, en consecuencia, no es absorbido por el frui, ni el frui se opondrá a la bondad recta, sino que todo caminará en la concordia del amor por una comprensión fielmente valorada del ser y del actuar. El ser nunca puede ser absorbido en su ontología, abandonado por la voluntad en el frui, sino comprendido por la libertad de amor, que regula en rectitud todo deber-ser y todo deber-hacer. Si el Ser $\longrightarrow$ Dios- - es la meta de la voluntad, toda actuación humana deberá ser una ida a El con la comprensión amorosamente fiel de todos los demás seres-cosas, o acciones-valor. Así, nunca puede haber arbitrariedad desordenada, sólo sí una voluntad discreta y 
conforme, regulada por el juicio verdadero, que es reconocimiento de todo en todo el ser.

En la elección siempre hay juicio de interés, noble o bajo; pero siempre en consonancia con la importancia que nosotros le atribuímos a la cosa o ser elegido. En el escogimiento siempre hay un algo que mira hacia nosotros, un juicio de perfección de lo escogido, como bueno, útil, favorable... Si en la elección entra el interés, en el escogimiento forma parte importante la fineza, que es reconocimiento del mérito, que conforma al ser que intentamos hacer nuestro; es perfección en captar modos y matices esenciales; es libertad respecto a lo aparente y monstrenco: es elegancia y es todo, es delicadeza y es amor; es, más que elegir, un darse a quien escogemos para nosotros. La elección puede ser: esnobismo y amaneramiento, figurón más que realidad, exhibicionismo más que propiedad fundamental; puede ser sensualidad y glotonería. Y cuando esto sucede, la elección deja de ser elección, y se convierte en egoísmo. Los vicios no se escogen, se eligen; se va hacia ellos, se hunde uno en ellos. En la elección dentro de la voluntad puede haber esclavitud de la misma voluntad; no así en el escogimiento, que es acto sublime de vendad y de bien ${ }^{101}$.

En la elección entra siempre un mucho de egoísmo, que no conoce la voluntad cuando se coloca en situación de escogimiento. Cuando la voluntad escoge, siempre hay en ello un proceder racional, con el que no es reducida por nada ni por nadie; ni tampoco reduce, sino que aclara conceptos y descubre realidades de verdad y de bien. Si la voluntad tiende a la posesión, con todo, en el escogimiento, más que poseer, da y se entrega a sí misma, amando con libertad, y reconociendo al otro en su ser y en sí, no usándolo - abusando- como medio. Sólo la voluntad' será libre, cuando se convierta en libertad de entrega en el acto mismo del escoger. El escoger implica siempre amor y nunca egoísmo; por eso, el escogimiento - repetimos- es entrega más que recepción. Y no se crea que esto es restricción de la voluntad; más que eso es abundancia de perfección de la voluntad. Con esto el hombre camina más en desenvoltura por falta de obstáculos; más en libertad por más abundancia de perfección. "Mientras el poeta corrige y sustituye una palabra por otra, puede elegir una entre muchas; en el momento en que brilla la "única", la insustituáble, ya no puede elegir: "es escogida". El santo no tiene

101 Remitimos al lector a la obra de F. M. ScIACCA, La libertad y el tiempo, trad. de Juan José Ruiz Cuevas. Edit. Luis Miracle, Barcelona 1967. 
nocesidades de nada, aun dando oídos a las necesidades corpóreas; no elige, acepta lo que le damos, porque ha escogido a Dios" ${ }^{102}$.

Es la voluntad-consciencia la que reúne en unidad solidaria lo que pudiera andar en dispersión: inquietud del espíritu y voliciones de la carne - exigencias humanas-, como una gestación tremebunda, antecedente a la generación doloridla del tiempo-historia, almáciga y almazara del hombre entero, porque de la carne y del espíritu se amasa el mérito de cada acción del presente. La voluntad, actuándose, con la acción realiza sus posibilidades múltiples; y al actualizarlas, engendra los momentos del tiempo, el presente-acción, el pasado-historia y el futuro-esperanza. Las posibilidades son siempre en presente, pero dirigidas a una acción futura, que se realizará en presente. Así, el porvenir no es un dato, ya dado en sentido determinista, sino una previsión en la que la voluntad juega un papel importantísimo en la decisión última a la hora del actuar. El pasado no sucede al porvenir, no nace ni arranca de él, ts la voluntad con su libre determinarse la que le hace caminar hacia la realización de un presente in consciencia, para quedarse siempre en pasado. Sólo la voluntad es madre del presente-tiempo desde el porvenir, porque la decisión se toma en un ahora relacionado, es verdad, con un después, que va hacia el ayer, ya realizado.

El tiempo es un grito del alma que va en busca de la realización ontológica de su ser en la existencia, o una opción fundamentalmente radical para buscar un asiento a la ansiedad con que la penetra y con que traspasa lo caduco de la temporalidad. Junto a esta aspiración a lo etenno hay un peligro esencial, un abismo o una negación, revelante de la tragedia del tiempo humano, que se asienta en el corazón, en el plano del querer y de la libertad. Una nueva dimensión humana del tiempo. "Ahora mis años se pasan en gemidos" ${ }^{103}$. La herida del tiempo - de las cosas temporales y mudables - se centra en el alma; o mejor, el alma herida toma una nueva visión original del tiempo en el concepto de pecado, y con él el de temporalidad. Ya el tiempo es un paso, un paso al vacío y a la muerte. Y siendo el alma inmortal, siente más hondo ese vacío que le deja la ausencia de la otra parte ontológicamente suya, el cuerpo. Siendo la constitución humana de plenitud, con ese instante de la muerte aprecia más el vacío de su ser.

El pecado, psicológicamente, implica la aportación de una escisión

102 Ibid. o. c. 78.

103 Conf. XI, 29, 39, PL, 32, 825. 
interna por la culpa ; y cuando ésta aparece en la intimidad hombre, todo lo humano entra en quiebra, y se va por el lado de la diáspora, en la disipación, en donde se da la fuga de valores. Entonces nos situamos, en frase agustiniana, en la vida mortal, o en la muerde vital ${ }^{104}$. En esta dimensión todo pasa; nos hacemos viejos, pasamos por la vida a caballo del tiempo, y nos situamos cada vez más al borde la muerte, robándonos la energía corporal. En este nuestro paso, y en el paso de la vida por nosotros, vamos forjando cada uno nuestra propia historia; y, todos juntos, la historia, que es también señal de un paso y de nuestra fugaz temporalidad. Estando embarcados en la fluencia de nuestro ser contingente, somos más murientes que vivientes, o abocados a la constante amenaza de dejar de existir ${ }^{105}$. Todo lo mortal está cargado de tempo- $"$, ralidad, y todo lo temporal camina hacia la muerte. La muerte es señal de temporalidad, como que entró en el mundo con el tiempo-pecado, y éste hace caminar hacia la disipación; y es sólo por el pecado por lo que hemos caído en el tiempo, en este tiempo que se acabará. Mortal y temporal tienen tanta trabazón y correspondencia entre sí, que se funden en la historia. "Por la enfermedad concebida en la instantánea corrupción del pecado, pendieron los hombres la estabilidad de la edad, y, a través de la mutabilidad de los tiempos, caminan hacia la muerte. Aunque vivieran muchos años, comenzaron a vivir en aquel día en que recibieron la ley de la muerte, que los condena a la decadencia senil. El tiempo se desliza sin hacer alto un solo instante, e insensiblemente va desbocado a su fin, no a un fin de perfección, sino a un fin que destruye" ${ }^{106}$. "Caídos en el pecado, llegamos a la senectud" 107. La vida humana, al producirse y parecer adelantar, más bien decrece y se aniquila ${ }^{108}$.

\footnotetext{
104 ...vitam mortalem an mortem vitalem (Conf. I, 6, 7, PL. 32, 663-664) ...moriebar vitaliter (Conf. VIII, 8, 19, PL. 32, 758).

105 ...at ego in tempora disilui (Conf. XI, 29, 39, PL. 32, 825). Non enim stat vel temporis puncto sed sine intermissione labitur, quidquid continuus mutatione sensim currit in finem, non perficientem, sed consummentem (De pecc. merit. et remiss. I, 16, 21, PL. 44, 120-121). Progressu animae usque ad mortalia lapsus est (De ord. II, 11, 31, PL. 32, 1.009).

106 De pecc. merit, et remiss. I, 1, PL. 44, 109.

107 Enn. in ps. 149, 1, PL. 37, 1.949.

108 Quod optas gradus aetatis, tot simul optas et mortes aetatum. Non sunt crgo ista. Nun deinde nati sunt tibi filiis in terra tecum victuri, an te potius exclusuri et sucessuri? Ad eos gaudes quae nati sunt, ut excludaris? Nati enim pueri tanquam hoc dicunt parentibus suis: "Eia, cogitate ire hinc, hagamus et nos mimum nostrum. Mimus est enim generis humani tota vita tentationis: quia dictum est: Universa vanitas omnis homo vivens (Enn. in ps. 127, 15, PL. 37, $16,186)$.
} 
Señal de paso es el tiempo en su contenido ontológico y psicológico, de caducidad y transitividad. Frente a una concepción del tiempo como permanencia y duración se presenta el otro lado del mismo como disipa. ción, paso o fugacidad. Si el alma es la originaria del tiempo psicológico, toda ella queda inmersa en él, y con él se hace temporalidad, y es distendida de esta forma por el tiempo: progreso-construcción, envejocimiento-castigo. El tiempo devora constantemente a los hijos del dolor y del trabajo; y si alguna vez nos inspira confianza y esperanza de vida, en su voracidad de las horas nos va dejando poco a poco frente a la muerte.

Como cualquier otra cuestión, como en cualquier otro problema que Agustín trata de estudiar y dar su parecer, cuando habla del tiempo, lo trata como algo que es, como tiempo-ser; de la misma manera que habla del hombre-ser, del bien-ser, de la verdad-ser. El ser es cuestión y problema, su pregunta y su respuesta. A pesarl de que muchos le achaquen el tiempo subjetivo ${ }^{109}$, cuando él habla del tiempo, casi siempre se refiere al tiempo psicológico, aunque sin descartar de sus escritos, especialmente en las Confesiones y en el De civitate Dei, el tiempo ontoló gico, concebido por él como un ser, que se nos arrima, y que con nosotros va del lado hasta la muerte, en donde para nosotros el tiempo también fenece. Y como cualquier otro tema, Agustín va también, en el del tiempo, del interior humano al ser, y del ser al hombre, y del hombre a Dios; en este caso a la eternidad, al Presente-Eterno. Para él el tiempo es ser, y como al ser lo estudia dentro de su intimidad, para llegar a descubrir dentro de él —de Agustín - la eternidad, también como ser. Por eso él quiere saber algo de la energía y naturaleza del tiempo ${ }^{110}$. Si es criatura, es ser; y si es ser, es algo ontológicamente real, ya nada subjetivo o psicológicamente mental. El alma no lo crea; lo que hace con él es medirlo tan sólo, y experimentarlo, porque en él queda transidamente inmersa; y porr el hecho de empezar a ser, como cualquier otra realidad, es ser ya en el tiempo: tiempo en el tiempo, no tiempo en el alma. Si en el alma se da una distensión, ésta no afecta en nada al tiempo en sí, sino en sus dimensiones o modos, que entrañan eso sí, conscien-

109 Por ejemplo, Russel, que quiere hacer ver que S. Agustín trata de un tiempo mental-subjetivo, en su obra Historia de la Filosofía occidental, Editorial Espasa-Calpe, Barcelona 1947, 383.

110 Conf. XI, 13, 16, PL. 32, 815. Illud certe accipiendum est in fide, etiam si modum nostrae cognitionis excedit, omnem creaturam habere inititur nec coaeternum esse creatori (De gen. ad litt. imper. lib. III, 8, PL, 34, 223; De civit, Dei, XII, 17, 2, PL. 41, 366-367), 
cia de duración, que sólo el hombre posee. Luego, el pasado, presente y futuro son modos del tiempo respecto al alma humana, al hombre, que es el que únicamente, entre los seres creados construye la historia. No obstante el tiempo también es para los demás seres, que comenzaron a serl in tempore ${ }^{111}$.

¿Cuándo medimos el tiempo? Ciertamente lo medimos en nosotros en el acto-acción que transcurre, no cuando ya ha pasado. El presente no sólo es praesens de praesentibus - visión intuitiva-, sino que también es presente-porvenir del futuro: es espera y memoria, todo asumido en la intuición presencial. Siendo la consciencia acto, que siempre está al principio - presente del ven-actuar-, el tiempo le es inagotable. Por eso, entendemos que la proyección de la voluntad-consciencia es ilimita$\mathrm{da}$, infinita en duración en la existencia a parte post, porque, dado ya su comienzo en la existencia, ya no se acaba, puesto que el alma - de quien la voluntad es facultad- es inmortal; y el tiempo-eviterno le es esencial. Luego, el futuro, que se la hará presente, se le vendrá incesantemente sin término en el fin; o el presente se le estará dando en constante suceder, si lo queremos entender así para distinguirlo de la eternidad a parte ante y aparte post del tiempo. El tiempo quedará constituído en la razón del ser, que por ser ser, siempre es-será.

Cada hombre es dueño de su tiemponhistoria, porque sus acciones pasan, y son historia. La humanidad hace historia, y es también dueña del tiempo. Las acciones son tiempo y son historia, porque, hechas conscientemente y libremente, se distinguen de cualquier evento físico, que no tiene libertad. Para el evento físico el presente es un necesario ligado a las circunstancias-ley, que otro determina y a las cuales lo físico está enredado. El hombre no es así; porque, colocado en un punto-inicio, actúa sobre él, no en él encerrado, y lo somete: esto es escoger su destino y engendrar su tiempo. La libertad-consciencia está sobre el tiempo y es antes que el tiempo, porque antes de mi libertad-consciencia no hay tiempo-mío, y sólo si el acto con que Dios me crea.

Mantener la unidad dialéctica en la unidad del tiempo es oficio de la consciencia. La meditación agustiniana es profunda en los tres modos del tiempo. En ella trata de conseguir la unidad del tiempo, o más bien la unidad de la consciencia a través del tiempo. De esa meditación con-

111 Cum ipsa natura, quam Deus fecit, tempora esse coeperunt (De ge. contr. manich. I, 2, 4, PL. 34, 175). Procul dubio mundus non est factus in tempore, sed cum tempore (De civit. Dei XI, 6, PL. 41, 322). 
cluye que todo puede reducirse a presencia en la consciencia, en la que la voluntad impera en todo momento. Así, hay consciencia de pasado y consciencia de futuro, por lo que puede haber intuición consciente de presente. Todo lo humano es consciencia, todo, todo lo que pasa y ha pasado por mí, y por donde yo he pasado y paso. Consciencia de to pasado ya no es consciencia de lo que aún no es y será: recuerdo-memoria para que se me dé en presencia, pero no-comprometido ya en la acción. El pasado ya no es vocación, sino grito de persuasión para una re-evocación. Lo re-evocado ya no puede vivirse; sí, a lo sumo, sacar de ello consecuencias aleccionadoras de escarmiento o de empuje: he aquí la influencia idel pretérito. El pasado ya no se desvinculó ontológicamente del presente, y ya no ofrece responsabilidad del actuar el presente, porque no lo es; porque no es presente del pasado y del porvenir, sólo sí pasado de un presente que fue y pasado del porvenir.

El pasado engendra nostalgia: "todo tiempo pasado fue mejor". El pasado es opción al recuerdo; y, por ser recuerdo, es muerte del tiempo, contingencia de las cosas contingentes pretéritas en no-ya-presiencia. Y me entrego al idulce recuerdo, porque soy yo el que va pasando; y, pasando, me hago más viejo, y no dispongo ya de lo que antes tenía a la mano. Por eso, la nostalgia, que es evasión en lo infinito que niega el pasado, me hace codiciar lo que no es ya, porque nunca lo podrá ser, y me hace olvidar un presente, quizá amargo en algún sentido. Sólo se tiene nostalgia del pasado, cuando el presente es pesadez y el futuro esperanza incierta de placidez. Cuando hay nostalgia, hay no-reducción a la trivialidad de lo diario, falta de capacidad de asumpción de lo bueno del presente, o de lucha para conseguir la sencilla grandeza de vivir la epopeya del instante sin interés y sin estrépito.

Así colocado yo, con amargura de presente, sólo miro al futuro como situación de lo verdadero, bello, hermoso y bueno. Y me digo a cada momento: "mañana mejor, mañana. Mejor que ayer, que hoy; mañana encontraré lo bueno y hermoso". Y todo yo me proyecto hacia el mañana; y lo hago presente en mi consciencia; y esto es para mí esperanza, que me aleja del presente y me hace renegar del pasado. Es la ilusión del vivir; es la contingencia en acción; es la consecuencia de una culpa, que sobre mí carga, y me lanza fuera de la experiencia del hoy amargo, en la creencia de que algo mejor me vendrá. Así, vivo del porvenir y en el porvenir, que lo hago presente en mi consciencia. La anticipación del porvenir en mi consciencia engendra expecta- 
ción, que es morir un poco, y querer morir totalmente al presente y al pasado, y esperar y confiar en la felicidad que se nos vendrá, porque tiene que venir. Y nadamos en la esperanza-expectación como en un mar de delicias. "Soñar es necesario"; y el hombre cuando se lanza al futuro y lo hace presencia en su consciencia, sueña, porque siente necesidad de soñar, de evadirse al tiempo y de sobreponerse al tiempo. En los sueños vive uno feliz; porque también la esperanza hace felices a los hombres. ¡Ay del que no sueña, porque no sabe soñar, o porque no quiere soñar! En ése no tiene cabida la esperanza, origen de muchos alumbramientos dichosos. Soñar es también hacerse el muerto, nadando sobre el mar de la realidad, para contribuir a realizarla. La consciencia - grávese esto muy bien - es la potencia humana, que en la dialéctica de la vida es capaz de unir -reducir a unidad — todo lo humano, desde el tiempoinicio hasta el tiempo-existencia: desde el nacer hasta el hacer en la inmortalidad del cielo.

San Agustín, además de hablar del tiempo psicológico, trata también del tiempo ontológico, de un tiempo en función algo real, de algo que es ser; de un tiempo efectivo, que empezó a ser cuando todo lo que se hizo fue hecho. Pero a San Agustín $\rightarrow$ y a todos- le resulta muy difícil definir el tiempo real; pero lo que nadie le puede arrebatar es que sabe qué cosa es el tiempo. Es una noción que se le da en la intuición, como el yo íntimo, que se le da en el si-mismo y que no sabe tampoco decirnos con palabras qué cosa es. Porque una cosa es la cosa en sí y otra la idea que de ella podamos tener. Lo mismo para el tiempo: una cosa es el tiempo y otra la idea que tenemos de él; pero nadie duda que es una relación de las cosas creadas, mudables y contingentes, a lo eterno, a la misma eternidad inconmutable y permanente.

Como nosotros trabajamos con seres, con lo que se nos pone ahí, frente a nosotros, por eso, no es muy difícil captar lo que en nosotros se nos da en una dación íntima de intuición. El tiempo es una de esas daciones intimas, que, siendo ser, se nos escapa al querer comprenderlo. El ser ideal-intencional del tiempo, al ser una relación de idea-ser, se nos va al intentar comprenderlo en los extremos de la relación con los que se nos da y con los que es. Y así nos dice San Agustín que el tiempo es el movimiento que en el tiempo se nos da, y que éste no puede existir sin el movimiento ${ }^{112}$, sin ese sucederise constante de los seres ${ }^{113} \mathrm{y}$ sin la

112 Non est ergo temporis corporis motus (Conf. XI, 24, 31, PL. 32, 821-822).

$113 U b i$ (in aeternitate) nullum est tempus, quia nulla mutabilitas est (De 
eternidad -el otro extremo de la relación-, siendo la eternidad la explicación causal y eficiente del tiempo en su ser y sentido ${ }^{114}$. Así, la eternidad exige que el tiempo se numere en instantes - pasado, presente y futuro-, y la que efectúa la salida de cada ser creado a su medida y dimensión temporall ${ }^{115}$.

Cada cosa, y el hombre en particular, tiene su medida en relación a la eternidad, centro de su duración. En esta duración el hombre realiza su existencia y construye la historia, su propia historia. Al constituirse el hombre, al hacerse cada día, va al mismo tiempo realizando su propio ser. $\mathrm{Y}$ en este realizar-su-ser el hombre, llevado conscientemente por la acies cogitantis, se planta en el tiempo y lo concibe como un gran receptáculo, en el que comprende que se desarrolla la duración, de un atrás hacia adelante con un instante de presencia a, en y con las cosas, los seres, en y consigo mismo. Luego, los movimientos de sí mismo y de los demás le dan la noción del movimiento y del tiempo. Luego, también los movimientos le sirven para medir y comprender el tiempo, y el tiempo para comprender los movimientos.

San Agustín se da muy buena cuenta de que esto no es el tiempo, sino algo para explicar que esto no es el tiempo ${ }^{116}$. El tiempo en sí está más allá de toda medida. Siendo concreto, también es universal, trasciende lo finito de las cosas y su movilidad, siendo todo él movilidad pura. Para comprenderlo hay que partir de una relación entre movimiento y eternidad, entre pasajero y permanente. Eso será el tiempo, que a todos nivela, haciéndonos viajeros y temporales.

Hay un peligro para el alma en la doble dimensión del tiempo. Viviendo ella misma en el tiempo y tocando casi la eternidad, en lo más profundo de sí misma, allí donde toda ella es presencia, corre el peligro de un falseamiento, si busca en las cosas temporales esa eternidad que entrevé en sí misma y se plantifica equivocadamente en lo caduco. Si esto le acontece, le ocurre un desgarramiento, porque las cosas "huyen para no ser, desgarran el alma con deseos pestilenciales; y ella quiere el ser

mus. VI, 11, 29, PL. 32, 1.179) ...ipsa mutabilitas apparet, in qua sentiri et dinumerari possunt tempora, quia rerum mutationibus fiunt tempora, dum variantur et vertuntur species (Conf. XII, 8, 8, PL. 32, 829).

114 Et vidi quia non solum lucis quaeque suis conveniunt, sed etiam temporibus, et quia tu, qui solus es aeternus, non post imnumerabilia spatia temporum, et quae praeteriunt et quae praeteribunt, nec abirent nisi te operante et manente (Conf. VII, 15, 21, PL. 32, 744).

115 De musica VI, 17, 57-58; VI, 11, 29, PL. 32, 1.191-1.193; 1.179).

116 Conf. XII, 13, 16, PL. 32, 831-832; De gen. ad litt. imperf. lib. 6, 26, PL. 34, 230-231. 
y ama el descanso en las cosas que ama. Mas no halla en ellas dónde, por no permanecer. Huyen, y quién podrá seguirlas con el sentido de la canne?" 117. "Muchos de gusto pervertido aman más el verso que el arte con que él se construye, por buscar más el halago del oído que el de la inteligencia; de igual modo, no pocos se perecen por lo temporal, mas dejando a un lado la divina Providencia, que forma y dirige los tiempos; y, en el amor a lo fugitivo, no quieren que pase lo que aman, y son tan insensatos como si alguien en el recitado de una poesía famosa quisiera estar oyendo siempre una sola sílaba" ${ }^{118}$. Siendo esto una avers:ón del sentido de dirección, es además un toncimiento de la concepción del tiempo. El tiempo siempre corre. Por eso, comprendemos la angustia de Fausto, cuando grita: “¡Párate, tiempo, eres tan hermoso...!" Es también el grito humano por lo que tiene de acicate de eternidad, y que lo queremos convertir en profunda permanencia. El tiempo nos arrebata lo que queremos retener, y con ello nos introduce en el sentimiento terrible de la muerte; porque seraen-el-tiempo es ser-plara-un-término.

San Agustín tiene un sentido profundo de la presencia; y cuando la interpreta, siente y mide el tiempo, y lo hace desde este sentido presencial. Y esto no lo podría lograr, si un nudo fuerte de sentimiento y entendimiento no lo tuviera ligado a la eternidad en contacto ontológico. El tiempo con su fugacidad pone al hombre sincero en este contacto ontológico con lo eterno, y lo espolea a una superación propia y a un lanzamiento a la trascendencia por una intuición en lo permanente, del que su alma es un suspirar constante por la presencia en la permanencia. "No nos busques a nosotros - le dicen las cosas terrenas-; no es esto lo que tú deseas. Busca más arriba de nosotras" ${ }^{119}$. Porque las cosas son revelación de lo que son y de lo que ellas indican; son finalidad, nunca fin y término, sino camino al descanso en la eternidad: son espectáculo, nunca morada. "El pecado nos conduce a la mortalidad, a los tiempos que vuelan, a las edades que hacen envejecer: he ahí el hombre viejo. Convirtámonos al interior, y hallaremos al hombre nuevo" ${ }^{120}$. "El hombre es envejecido por el pecado, pero se renovará por la gracia" ${ }^{212}$. "En este mudarse pasamos de lo viejo a lo nuevo. Este tránsito se va haciendo mientras se cortompen las cosas exteriores y se

\footnotetext{
117 Conf. VI, 10, 15, PL. 32, 699-670.

118 I) vera Relig. 22, 43; 35, 65, PL. 34, 140; 151.

119 Conf. X, 6, 9, PL. 32, 783.

120 Enn. in ps. 38, 7, 9, PL. 36, 418-419, 420-421.

121 Ibid. 6, 9, PL. 36, 95.
} 
renuevan las interiores. Lo exterior paga un tributo propio a la naturaleza, hasta que llegue la muerte para renovarse después todo en la resurrección". En esta vida "no nos vestimos de tal manera de Cristo, que no dejemos de llevar algo del viejo Adán" ${ }^{122}$. "Para que llegues a ser plenamente, tienes que trascender el tiempo. Pero, ¿quién será el que pueda trascenderlo por sus propias fuerzas? Cristo es el camino, la verdad y la vida" ${ }^{23}$. "Une tu corazón a la eternidad" ${ }^{124}$.

$$
\text { P. Moisés M." Campelo, O. S. A. }
$$

122 Ibid. 38, 9, PL. 36, 420-421.

123 Ut ergo et tu sis, transcende tempus. Sed quis transeat viribus suis? (In Ionn. Evang. XXXVIII, 10, PL. 35, 1618). Ipsa est via quae est veritas (Ibid. XIII, 4, PL. 35, 1494). Amare itaque debemos per quem facta sunt tempora, ut liberaremur a tempore, et figamur in aeternitate, ubi iam nulla est mutabilitas temporum (In Ionn. Evang. XXXI, 5, PL. 35, 1638).

124 Enn. in ps. 91, 8, PI. 37, 1.176-1.177. 